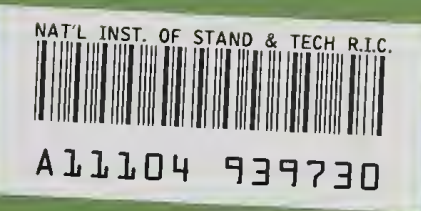

NBSIR 79-1790

\title{
A Comparison of American and European Ultrasonic Testing Standards
}

Sam Golan

Office of Nondestructive Evaluation National Measurement Laboratory National Bureau of Standards Washington, DC 20234

June 1979

Issued August 1979

Prepared for:

National Bureau of Standards

Department of Commerce

$-Q C$ Washington, DC 20234 

NBSIR 79-1790

"

\section{A COMPARISON OF AMERICAN AND \\ EUROPEAN ULTRASONIC TESTING \\ STANDARDS}

Sam Golan

Office of Nondestructive Evaluation

National Measurement Laboratory

National Bureau of Standards

Washington, DC 20234

June 1979

Issued August 1979

Prepared for:

National Bureau of Standards

Department of Commerce

Washington, DC 20234

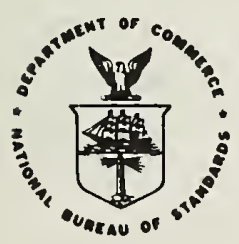

U.S. DEPARTMENT OF COMMERCE, Juanita M. Krops, Secretary

Luther H. Hodges, Jr., Under Secretary

Jordan J. Baruch, Assistant Secretary for Science and Technology

NATIONAL BUREAU OF STANDARDS, Ernest Ambler, Acting Director 

A Comparison of American and European Ultrasonic Testing Standards

\section{by}

\section{S. Golan*}

\section{ABSTRACT}

In this report twenty-seven general ultrasonic testing standards from eleven countries and international organizations are reviewed and evaluated. Also, thirty-seven ultrasonic testing standards for specific products, from five countries, are examined in order to evaluate their utilization of the general ultrasonic testing standards, i.e., the extent to which the procedures outlined in the general standards are applied by the product standards. Finally, the "universal" concept of ultrasonic testing standards versus the "specific", product-oriented concept is discussed.

* Permanent address, Israel Institute of Metals, Israel. This report was prepared while the author was on a temporary assignment to the NBS Office of Nondestructive Evaluation. 


\section{TABLE OF CONTENTS}

\section{Page}

Abstract

1. Introduction

2. Synops is and Evaluation of General UItrasonic Testing Standards

3. Utilization of General Standards in Product Standards

4. Discussion

5. References 


\section{INTRODUCTION}

Standards are used to assure uniform and reproducible measurements and to achieve acceptable levels of quality of products. Measurement techniques which are capable of expressing the required quality in quantitative terms with reasonable precision and accuracy can help to ascertain the true quality of a product. Unfortunately, NDE techniques generally, and the ultrasonic technique particularly, are quite limited in their ability to express quality in quantitative terms because our knowledge of the interaction between the ultrasonic field and the tested medium and of the relation between measured quality (changes in the energy field) and required quality (integrity) is limited to idealized, simplified models. These models usually do not adequately simulate real situations, which are far more complex. Consequently, ultrasonic test methods provide basically qualitative information. Ultrasonic testing standards, based on empirical methods and practical considerations such as cost, production and safety requirements, state of the art of instrumentation technology and personnel qualification, attempt to reach a certain degree of quantification and comparability, without which the use of the ultrasonic technique as a quality inspection tool would not be possible.

The need for standardization was apparent in the early stages of use of the ultrasonic technique. This led to local and national initiatives, the results of which were an output of various specifications 
and standards. Various reference blocks with flat-bottom hole, sidedrilled hole, notch, groove, slit, ball and bottom reflectors for the calibration of ultrasonic testing systems and for flaw characterization have been specified by different standards in different countries. The diversity does not necessarily reflect differences in product quality, but is rather a result of different approaches taken by different initiators.

A] though lists of ultrasonic standards have been published [1-3] this is believed to be the first attempt to synopsize and evaluate the most important national and international ultrasonic testing standards.

In most countries a central standards institution is responsible for the preparation and promulgation of national standards; for example, consider the British Standards Institute in the United Kingdom, Association Francaise de Normalization in France, Deutscher Normenausschuss in West Germany, etc. In the United States, however, many organizations prepare and promulgate standards. In a list of nondestructive testing standards and specifications prepared by the American Society for Nondestructive Testing (ASNT) technical council [3], more than ten U.S. organizations that promulgate nondestructive testing standards are listed. U.S. standards considered in this review are primarily American Society for Testing and Materials (ASTM) standards which have gained general recognition in the United States and are well known in other countries. 
Ultrasonic testing standards can be divided into two main groups; standards for general application and standards for the testing of specific products. This review is primarily concerned with the general standards, but standards which apply to a wide group of products characterized by their technology of production (welding, forging, casting, etc.) are also included.

The general standards address three main subject areas:

1. Evaluation and characterization of uitrasonic testing systems and system components.

2. Description of testing methods and testing procedures.

3. Reference blocks.

Usually a standard deals with more than one subject area. For instance, British Standard BS 4331 describes both the evaluation of systems and reference blocks. ASTM Standard E-164 is a recommended practice for the testing of welds and includes a description of reference blocks.

The standards are evaluated and discussed according to the following criteria: 
1. Whether the standard is simple to use.

2. The extent to which the standard is referenced in product standards.

3. The amount and the quality of information that the standard provides. 


\section{SYNOPSIS AND EVALUATION OF GENERAL ULTRASONIC TESTING STANDRDS}

A list of organizations, the standards of which are reviewed here, is given in Table 1. The general ultrasonic testing standards themselves are listed in Table 2.

\section{Table 1. Standards Organizations}

Standards

Country

Australia

Austria

France

International

Internationa 1

Netherlands

Sweden

United Kingdom

United States

Union of Soviet

Socialist Republics

West Germany
AS

ON

NF

IIW

ISO

NEN

SIS

BS

ANSI

ASME

ASTM

AWS

GOST

DIN

\section{Organization}

Standards Association of Australia

Österreichisches Normungsinstitüt

Association Francais de Normalization (AFNOR)

International Institute of Welding

International Organization for Standardization

Nederlands Normalisatic-Institunt

Sveriges Standardizezingskommission

British Standards Institution

American National Standards Institute

American Society of Mechanical Engineers

American Society for Testing and Materials

American Welding Society

Gosudarstviennye Komitet Standartov Sovieta Ministrov SSSR (USSR State Committee for Standards)

Deutscher Normenausschuss 
Table 2. General U1trasonic Testing Standards

\begin{tabular}{|c|c|c|c|}
\hline Country & Standard Number & Year & Page \\
\hline Australia & AS 2083 & 1977 & 11 \\
\hline \multirow[t]{2}{*}{ Austria } & ÖNORM DIN 54120 & 1973 & 11 \\
\hline & ÖNORM DIN 54122 & 1973 & 14 \\
\hline France & NF A04331 & 1969 & 11 \\
\hline \multirow[t]{3}{*}{ International } & ISO R2400 & 1976 & 11 \\
\hline & IIW V-461 & 1974 & 11 \\
\hline & IIW 450 & 1974 & 14 \\
\hline \multirow[t]{2}{*}{ Netherlands } & NEN 2510 & 1973 & 11 \\
\hline & NEN 2511 & 1972 & 11 \\
\hline \multirow[t]{2}{*}{ Sweden } & SIS 114240 & 1974 & 11 \\
\hline & SIS 114241 & 1974 & 14 \\
\hline \multirow[t]{5}{*}{ U. Kingdom } & BS 4331/Part 1 & 1968 & 17 \\
\hline & BS $4331 /$ Part 3 & 1974 & $11,14,18$ \\
\hline & BS 2704 & 1966 & 11,24 \\
\hline & BS $3923 /$ Part $1-3$ & 1968,72 & 30 \\
\hline & BS DD28 & 1973 & 34 \\
\hline \multirow[t]{8}{*}{ U.S.A. } & $\begin{array}{l}\text { ANSI/ASTM E-114 } \\
\text { ANSI/ASME SE-114 }\end{array}$ & 1975 & 36 \\
\hline & $\begin{array}{l}\text { ASTM } E-214 \\
\text { ASME SE-214 }\end{array}$ & 1974 & 37 \\
\hline & $\begin{array}{l}\text { ANSI/ASTM A-388 } \\
\text { ANSI/ASME SA-388 }\end{array}$ & 1978 & 38 \\
\hline & ANSI/ASTM E-317 & 1968 & 39 \\
\hline & ANSI/ASTM E-587 & 1976 & 46 \\
\hline & ANSI/ASTM E-127 & 1975 & 41 \\
\hline & ASTM E-428 & 1975 & 47 \\
\hline & ANSI/ASTM E-164 & 1974 & 11,48 \\
\hline & GOST 14782 & 1976 & 54 \\
\hline \multirow{2}{*}{ W. Germany } & DIN 54120 & 1973 & 11 \\
\hline & DIN 54122 & 1973 & 14 \\
\hline
\end{tabular}


2.1 IIW Calibration Block 1 and Its Use for Adjustment and Control of Ultrasonic Testing Systems

Block 1 (Fig. 1) has been adopted in numerous standards, most of which are listed below.

$\begin{array}{lll}\text { W. Germany } & \text { DIN } 54120 & \text { (1973) } \\ \text { Austria } & \text { DIN } 54120 & (1973) \\ \text { U. Kingdom } & \text { BS 2704* } & (1966) \\ \text { France } & \text { NF A04331 } & (1964) \\ \text { Netherlands } & \text { NEN } 2510 & (1973) \\ \text { Australia } & \text { AS } 2085 & (1977) \\ \text { Sweden } & \text { SIS } 114240 & (1974) \\ \text { U.S.A. } & \text { ASTM E-164 } & (1974) \\ \text { International } & \text { ISO 2400 } & (1972) \\ \text { International } & \text { IIW V-467 } & (1971)\end{array}$

\subsubsection{Synopsis}

The standards describe a calibration block and its use for system adjustment to test carbon and low alloy steel using normal and anglebeam contact techniques.

* In BS 2704 IIW Block 1 is referred to as A.2. 
The following operations may be performed using the block and its modifications:

1. Check of time base linearity.

2. Setting of range and zero point.

3. Determination of exit point of central beam of transducer.

4. Determination of angle of refraction.

5. Setting of working sensitivity.

6. Estimation of resolution.

\subsubsection{Evaluation}

The design of Block 1 permits the tester to perform the most common system adjustments. If additional parameters, such as beam profile and dead zone, are required, complementary blocks are necessary (see pages 18-23). Practical considerations are that the block has a rather complicated design and is somewhat heavy to handle, especially when slippery from couplant oil. IIW Block 2 (see pages 14-16) has been designed to overcome this deficiency. Block 1 is the most popular block in Europe, it is used by the welding industry in the U.S., and it is recognized by the international organizations, ISO and IIW. Its main advantages are that many important parameters which determine the quality of a test can be monitored with this single block and that it is applicable to both normal and angle-beam techniques. 

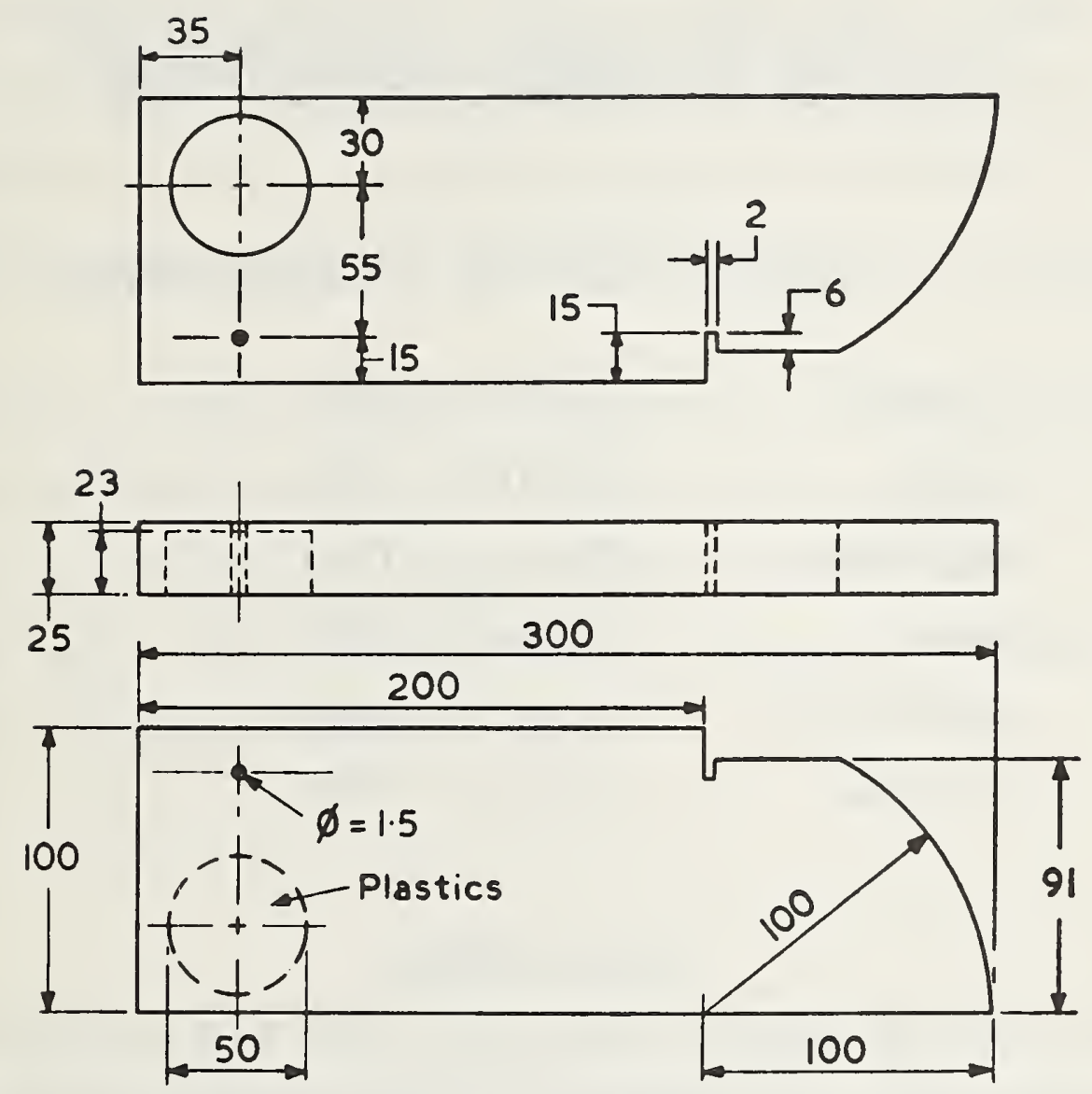

Unless otherwise indicated, all dimensions correct to $0.1 \mathrm{~mm}$
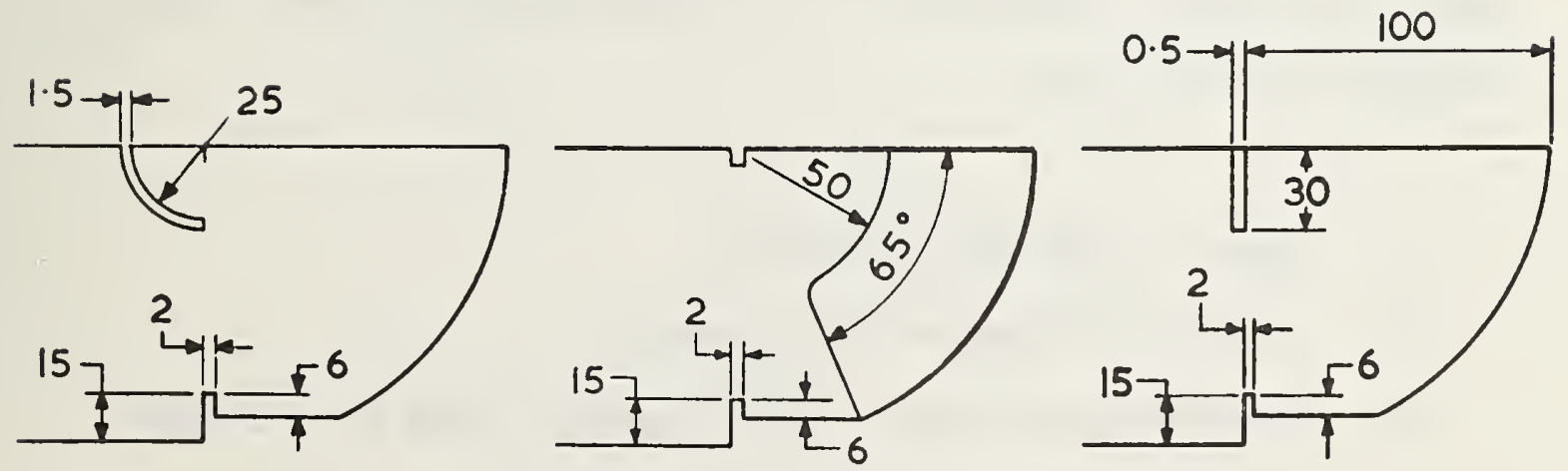

Figure 1. IIW Block 1 (BS A2 Block) and its modifications. (Illustrations from BS 2709) 


\subsection{IIW Calibration Block 2 and Its Use for the Adjustment and Control of UTtrasonic Systems}

Block 2 was adopted for use in the following standards:

$\begin{array}{lll}\text { W. Germany } & \text { DIN } 54122 & \text { (1973) } \\ \text { Austria } & \text { DIN } 54122 & \text { (1973) } \\ \text { Netherlands } & \text { NEN } 2411 & (1972) \\ \text { Sweden } & \text { SIS } 114241 & (1974) \\ \text { International } & \text { IIW } 450 & (1974) \\ \text { U. Kingdom } & \text { BS } 4331 / 3 & (1974)\end{array}$

\subsubsection{Synopsis}

The standards describe a calibration block (Fig. 2) and its use for system adjustment to test carbon and low alloy steel by normal and angle-beam contact techniques. The following operations may be performed using this block:

1. Check of time base linearity.

2. Setting of range and zero point.

3. Determination of exit point of central beam of transducer.

4. Determination of angle of refraction.

5. Setting of working sensitivity. 


\subsubsection{Evaluation}

IIW Block 2 is suitable for the most common types of system adjustment. The most important parameters of a system which determine the quality of a test can be monitored with this single block. It is applicable to both normal and angle-beam techniques.

It does not offer as much in scope as Block 1 , but it has the advantage of being much smaller and lighter (0.2 kg compared to $4.5 \mathrm{~kg}$ for Block 1). Because it is easy to handle, it is very practical to use in field tests. Thus, the test setup can be frequently checked and any necessary resetting accomplished. 

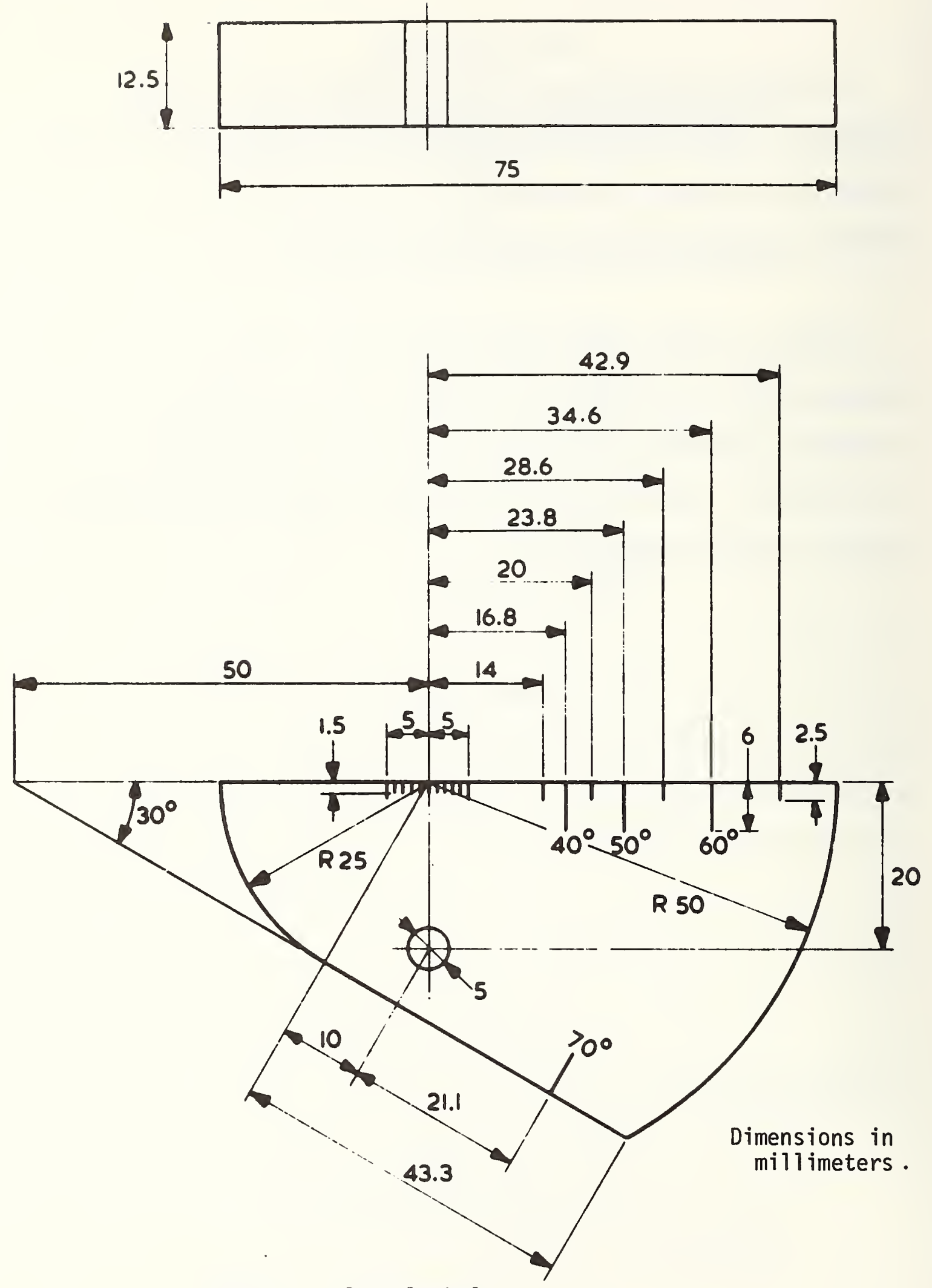

Figure 2. IIW Block 2

(IIIustration from B.S 4431 , parts) 


\subsection{Methods for Assessing the Performance of Ultrasonic Flaw Detection Equipment, Part 1 - Overal1 Performance, BS 4337 (1968)}

\subsubsection{Synops is}

This standard provides a method for evaluating the most basic performance requirements of $u l$ trasonic testing systems. Using IIW Block 1, the following system characteristics are determined:

1. Linearity of time base.

2. Linearity of amplification.

3. Resolution.

4. Maximum penetrating power.

\subsubsection{Evaluation}

The standard provides a simple method for evaluating four basic performance characteristics. This, together with BS 4331 Part 2 for electrical performance, is apparently the only standard in Europe for evaluating an ultrasonic testing system independently of specific test conditions. It is, however, limited in the sense that only the results from similar types of apparatus using similar transducers and identical coupling conditions can be compared. 


\subsection{Methods for Assessing Performance Characteristics of UTtrasonic Flaw Detection Equipment, \\ Part 3 - Guidance On The In-Service Monitoring of

Probes (excluding immersion probes), BS 4331 (1974)

\subsubsection{Synopsis}

This standard comprehensively covers the characteristics of normal and angle-beam contact transducers. Methods and blocks for evaluating the following parameters are specified:

1. Point of exit of central beam.

2. Beam angle.

3. Beam profile.

4. Dominant frequency.

5. Pulse length.

6. Dead zone.

7. Length of near field.

8. Signal-to-noise ratio.

9. Overall system gain (periodic check of stability).

10. Beam alignment. 
11. Depth resolution.

12. Angular resolution.

Some of these parameters are determined with the conventional European blocks, IIW Block 1 (Fig. 1) or IIW Block 2 (Fig. 2). Other parameters are determined with specially designed blocks, some of which are shown in Figures 3-5.

\subsubsection{Evaluation}

BS 4331 Part 3 is the most comprehensive standard for evaluating the characteristics of contact transducers in in-service conditions. It covers many parameters of the transducer which most strongly affect the quality of flaw detection. The evaluations of beam profile, beam alignment, depth resolution, angular resolution and near field, which are often overlooked in other standards, are specified here.

Unlike Parts 1 and 2 of this standard, which describe a general evaluation method for the overall performance and the electrical performance of equipment, this part is intended to standardize checking procedures which should be performed under conditions simulating the specific work to be performed. It is not a general characterization of the transducer itself, but a characterization of its performance under real and specific conditions. 
The presentation of the standard is very clear and accurate and includes many drawings to illustrate the text. The evaluation procedures are simple and can easily be performed by the tester under inservice conditions. 


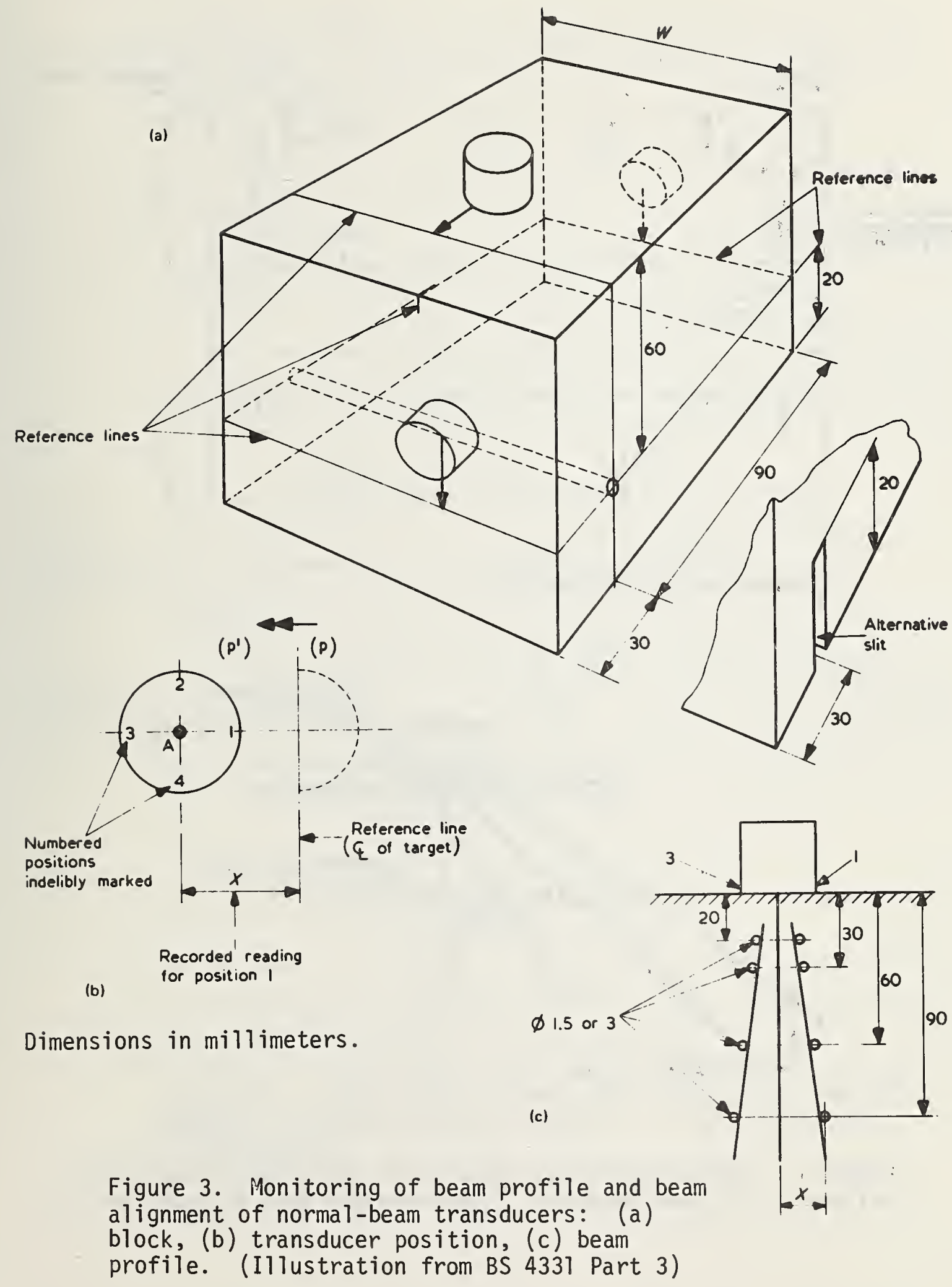




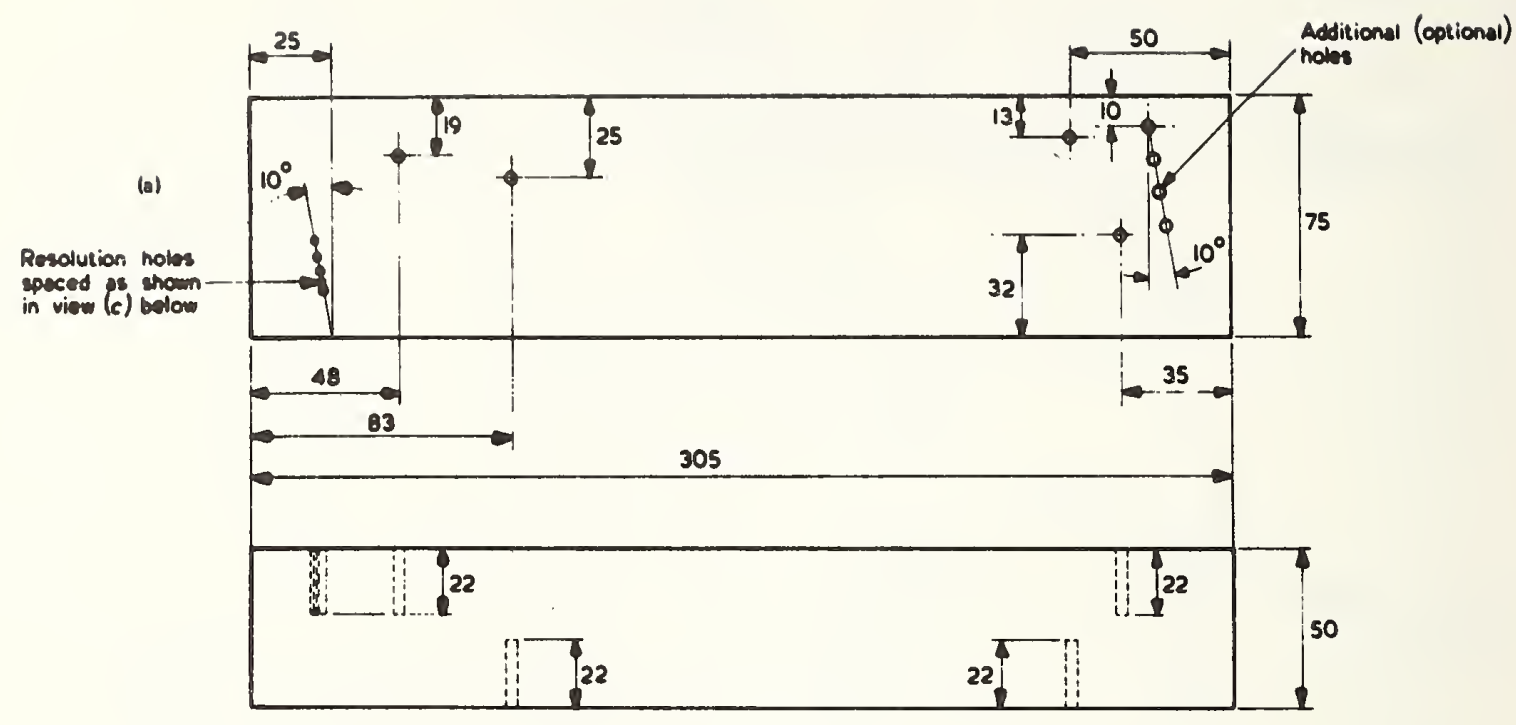

(Dimensions in millimeters)

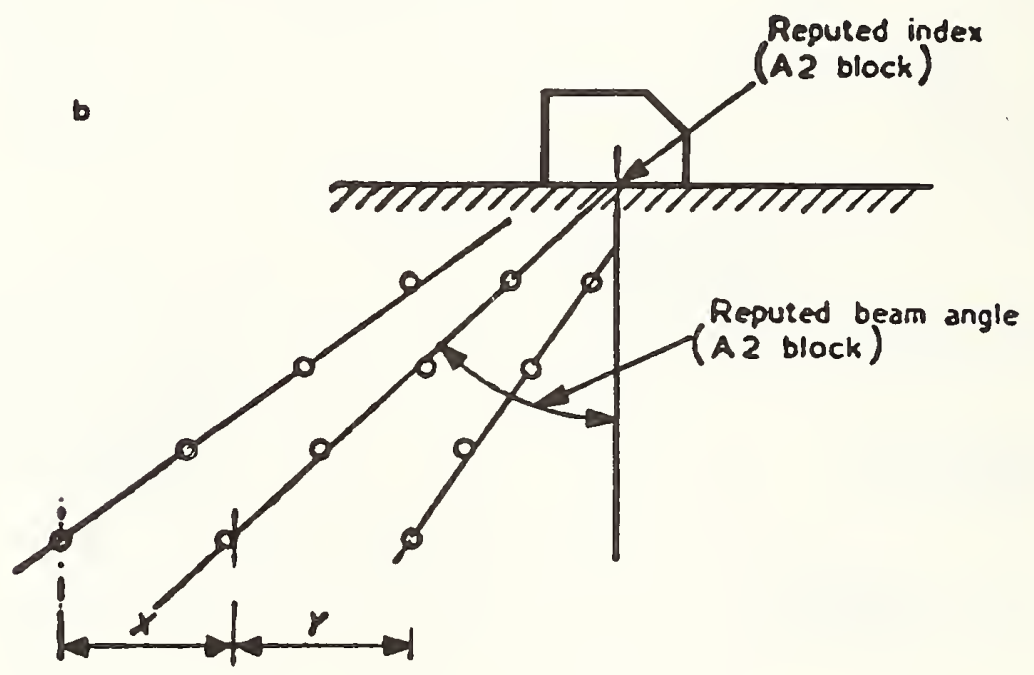

Figure 4. Monitoring of beam profile of angle-beam transducers:

(a) block, (b) beam profile. (I liustrations from BS 4331 Part 3) 


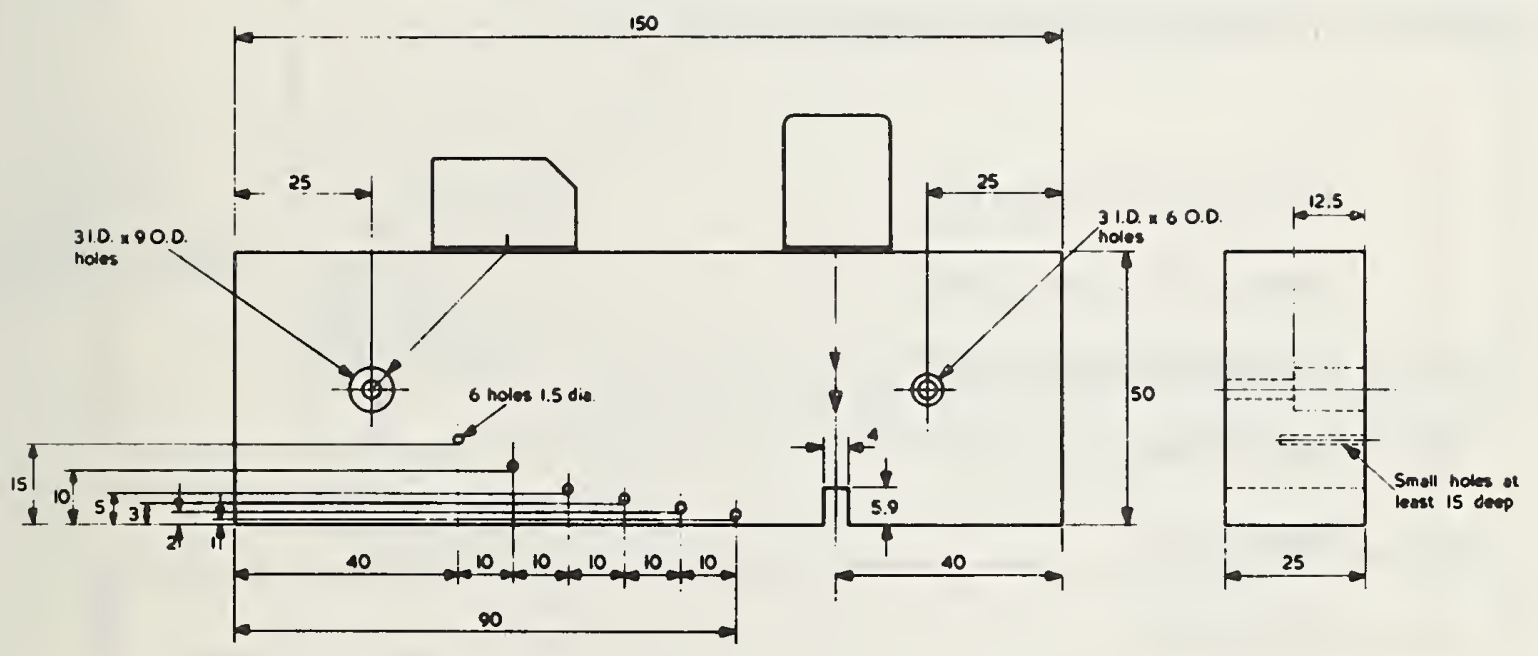

Dimensions in millimeters.

Figure 5. Block used to check depth resolution, dead zone dominant frequency and pulse length. (IIlustration from BS 4331 Part 3) 


\subsection{Specification for Calibration Blocks and Recommendations}

\section{for Their Use in UTtrasonic Flaw Detection, BS 2074 (1966)}

\subsubsection{Synops is}

This standard contains specifications for the design and application of different ultrasonic calibration blocks. These blocks are used to test carbon and low alloy steel with normal and angle-beam contact transducers. The various blocks enable adjustment and evaluation of the following parameters:

1. time base linearity

2. range and zero point

3. working sensitivity

4. beam characteristic

5. dead zone

6. resolution

Block BS Al (Fig. 6) is used to set the sensitivity and to characterize the beam of an angle-beam transducer. Block BS A2 is identical to IIW Block 1, which was described on pages 11-13 (Fig. 1). Block BS A3, known as the Sulzer Block (Fig. 7) has the same application as Block $A 2$. 

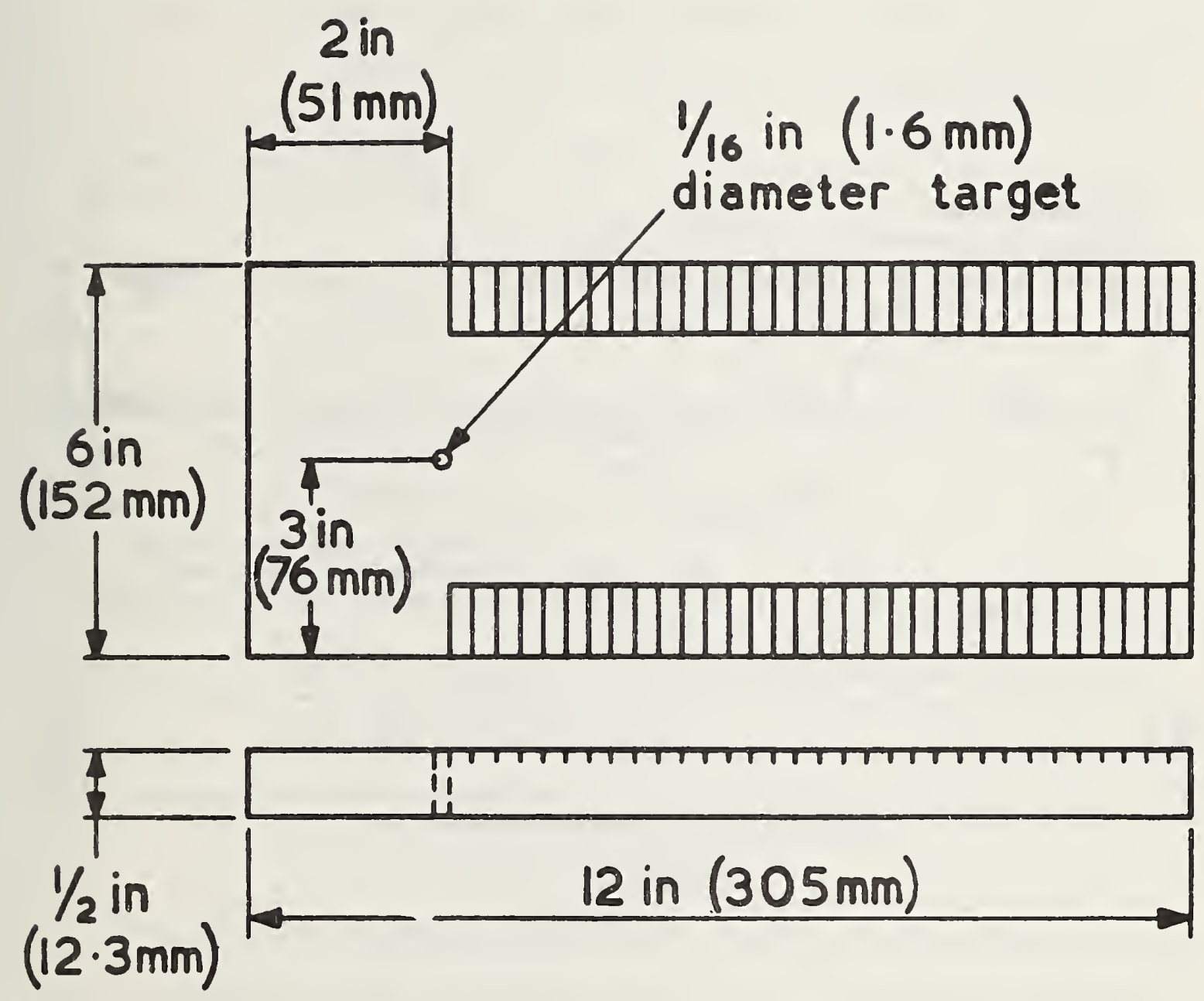

Tolerance on length and width \pm 0.05 in $(1.25 \mathrm{~mm})$ Tolerance on thickness \pm 0.005 in $(0.125 \mathrm{~mm})$

Figure 6. B.S Block AI (Illustration from B.S 2704) 

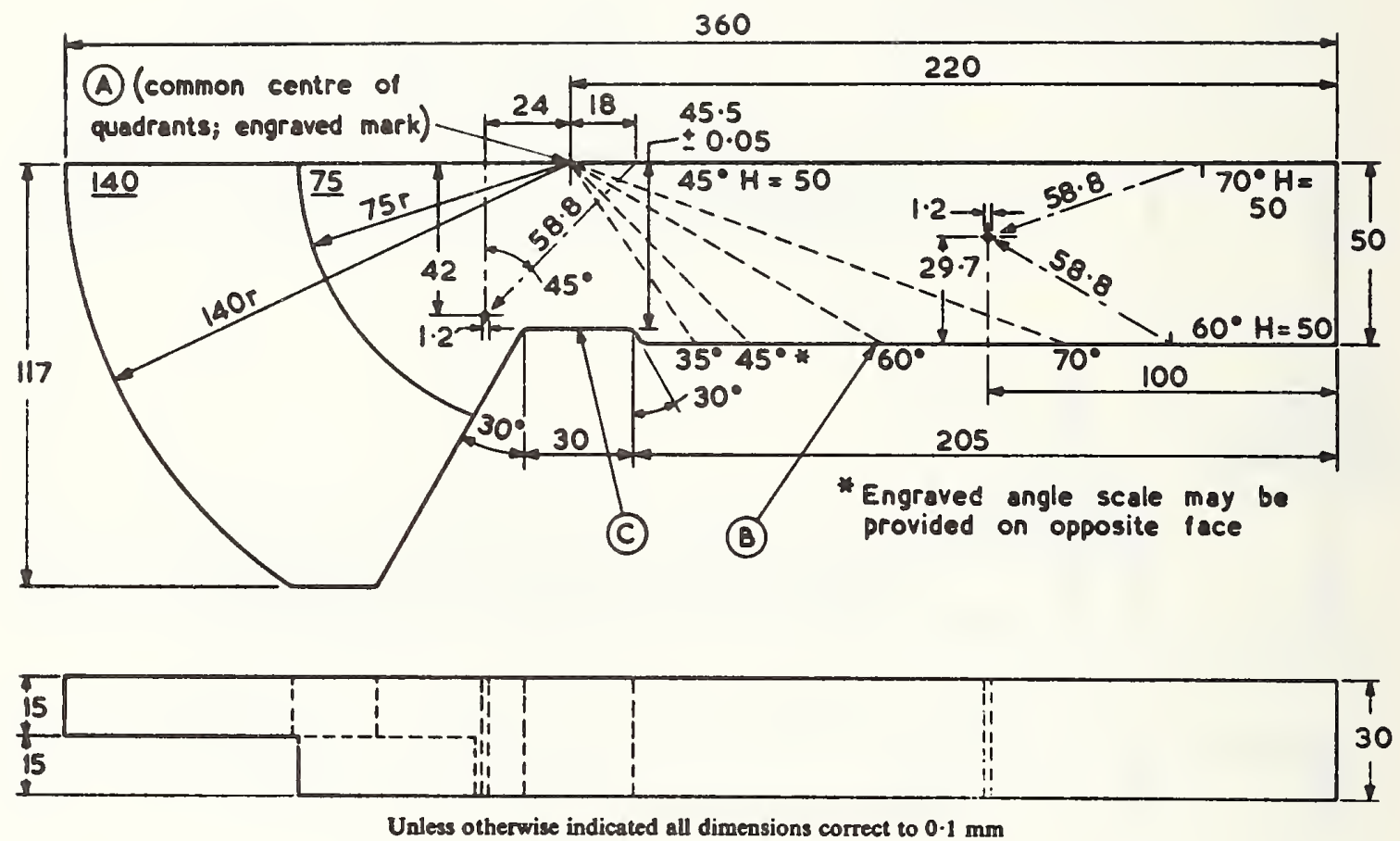

Figure 7. B.S Block A3 (I1lustration from B.S 2704) 
The standard is extended by several appendices which contain the following information.
App. A Determination of angle and index of angle beam transducers, and the time base linearity for the contact angle beam technique.

App. B Description of transducer radiation pattern.

App. C Definition and method of monitoring of the effective beam form.

App. D Description of two types of flat-bottom hole reference blocks; one each for use with compressional and shear waves (see Figs. 8 and 9).

\subsubsection{Evaluation}

This standard together with BS 4331, previousiy described, are the basic ultrasonic testing standards in the U.K. It contains a detailed description of reference blocks A1, A2 (IIW Block 1) and A3 (Figs. 1, 6 and 7) and their applications. The presentation is very clear and the text contains many explanatory drawings. 


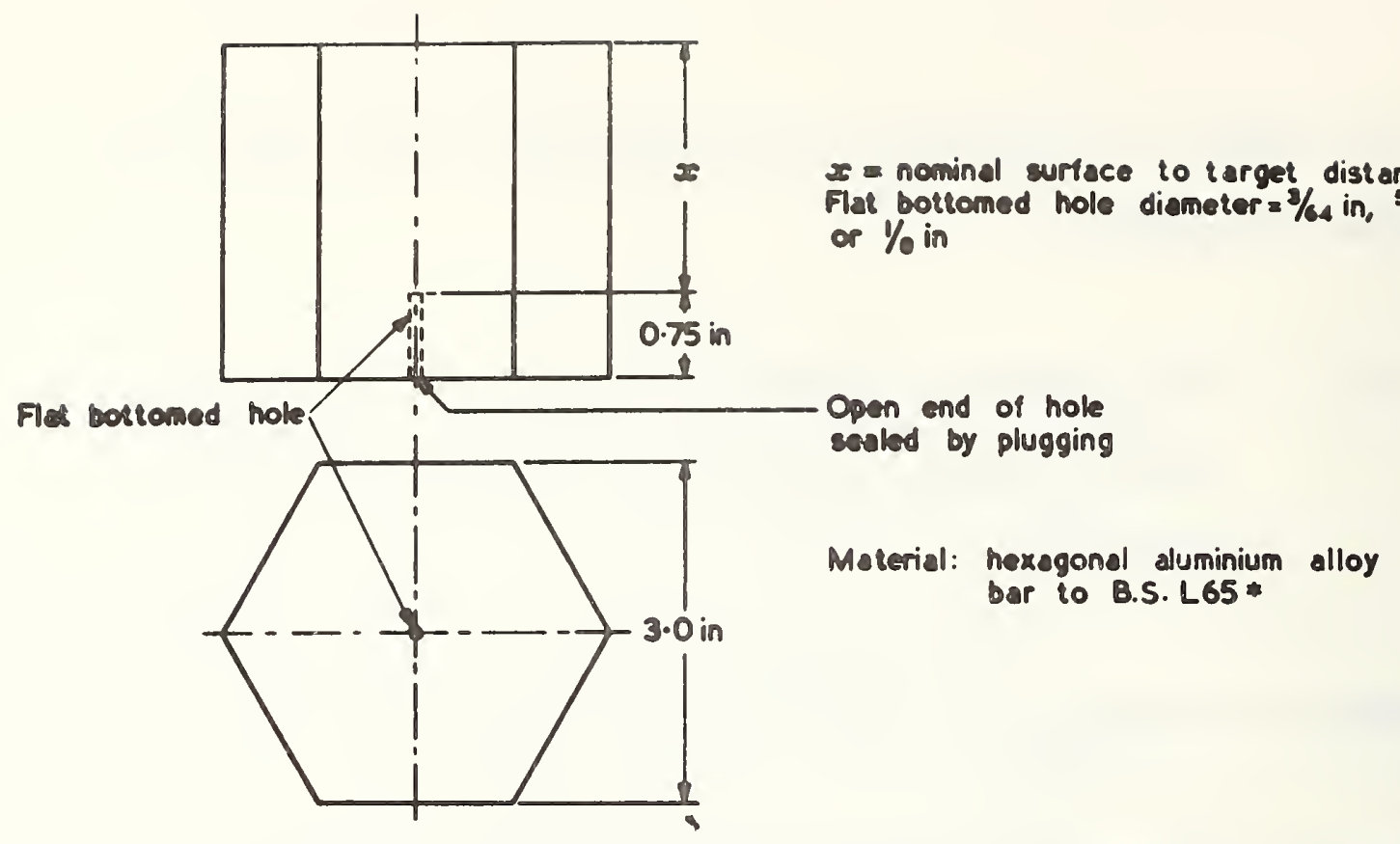

Figure 8. Aluminum flat-bottom hole reference block. (Illustration from BS 2704)
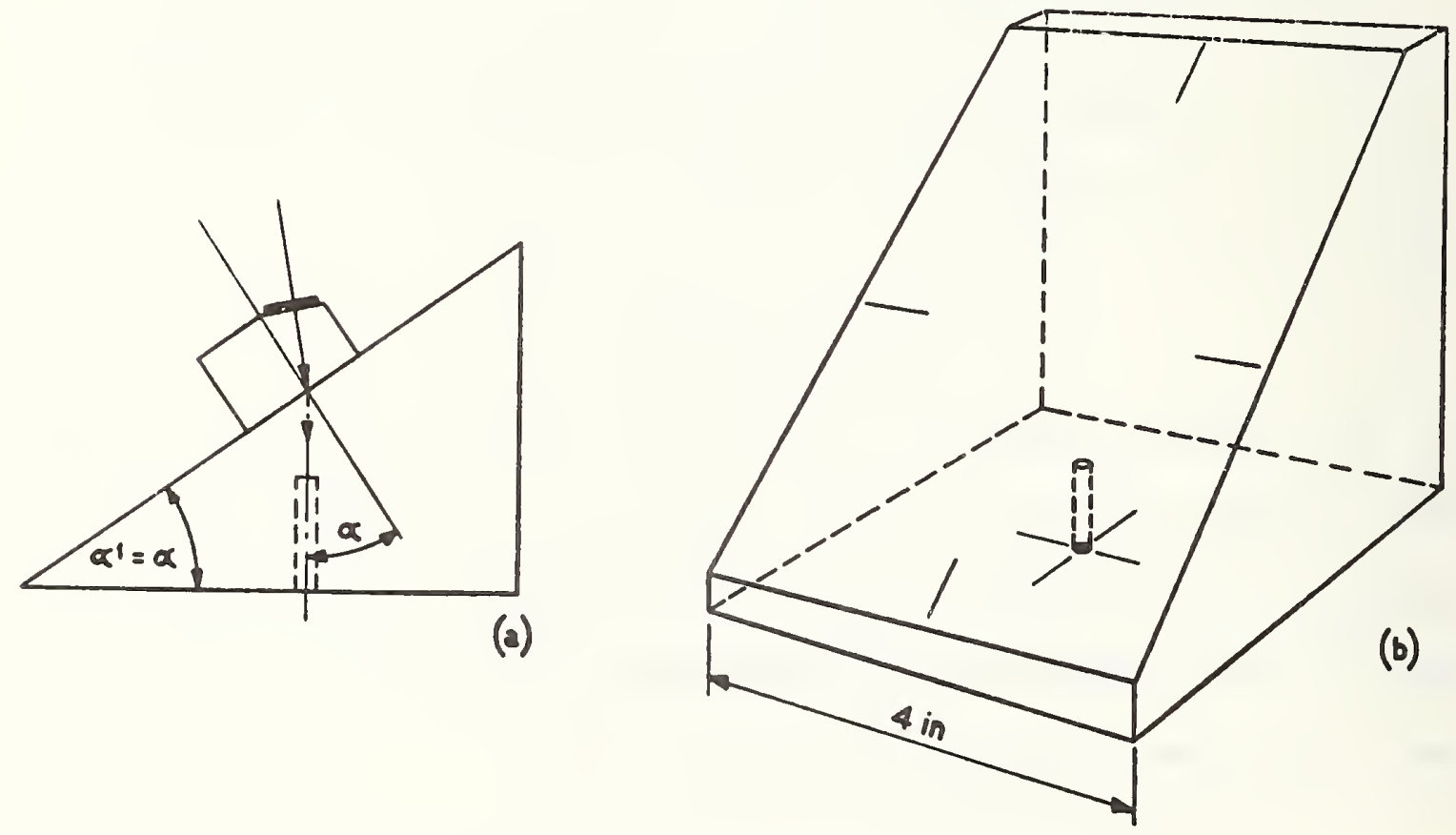

Figure 9. Reference block for use with shear waves. (Illustration from BS 2704) 
This standard, BS 4331 Part 3 and ASTM E-127 are apparently the only existing standards which contain information on ultrasonic transducer beam characterization. This is also the only standard which describes flat-bottom hole wedge-type reference blocks for use with shear waves. It seems, however, that the A.1 block and the wedge-type blocks have not gained wide recognition. The characteristics monitored with the block can be determined with the more universal IIW Block 1. Instead of using a series of wedge blocks with different angles, hole diameters and hole depth for shear-beam characterization, it is more convenient to use the block shown in Figure 4. 


\subsection{Methods for U1trasonic Examinations of Welds, BS 3923}

Part 1. Manual Examination of Fusion Welded Butt Joints in Ferritic Steels (1968);

Part 2. Automatic Examination of Fusion Welded Butt Joints in Ferritic Steels (1972);

Part 3. Manual Examination of Nozzle Welds (1973).

\subsubsection{Synopsis}

The three parts of this standard provide methods for examining butt welds in ferritic steels. The performance characteristics of the ultrasonic system and the transducer specified in the standard are calibrated and evaluated according to BS 2704 (see pages 24-29) and according to procedures described in BS 4331, Part 3 (see pages 18-23). The scans are specified so as to insure examination of the complete volume of the weld for both longitudinal and transversel defects. Guidance on transducer selection is given, and procedures are suggested for determining the location and for estimating the size and nature of flaws. The contact method is applied for manual examination (Parts 1 and 3 ) and the gap or immersion method for automatic examination (Part 3 ). 
Parts 2 and 3 also contain a detailed description of procedures for achieving a given sensitivity, for measuring attenuation coefficients and for evaluation of flaw size using DGS (Distance-Gain-Sensitivity) diagrams for normal and angle-beam transducers (see Figs. 10,11).

\subsubsection{Evaluation}

This is a very practical and detailed description of methods by which a complete ultrasonic examination of butt welds can be performed. The procedures are clearly and simply set forth. In addition, this is one of the few standards which describe the use of the DGS diagrams for flaw sizing. However, the accuracy, with which the flaws can be characterized is largely dependent on the performance characteristics of the system, the characteristics of the particular weld, and the skill and experience of the tester. Consequently, the level of quantification is quite limited. 


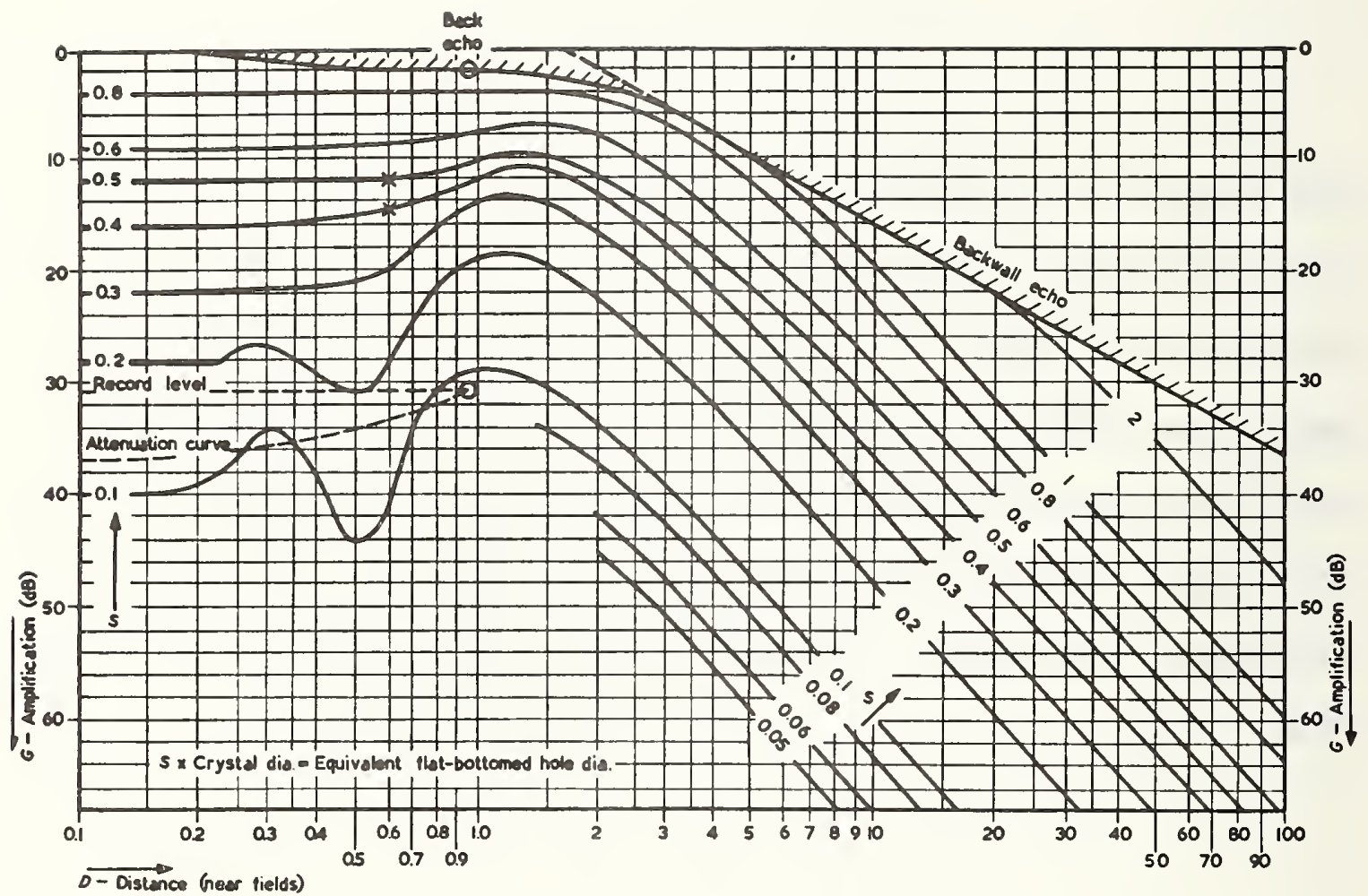

Figure 10. Typical D.G.S. diagram for normal probes. (IIlustration from BS 3923 part 2) 


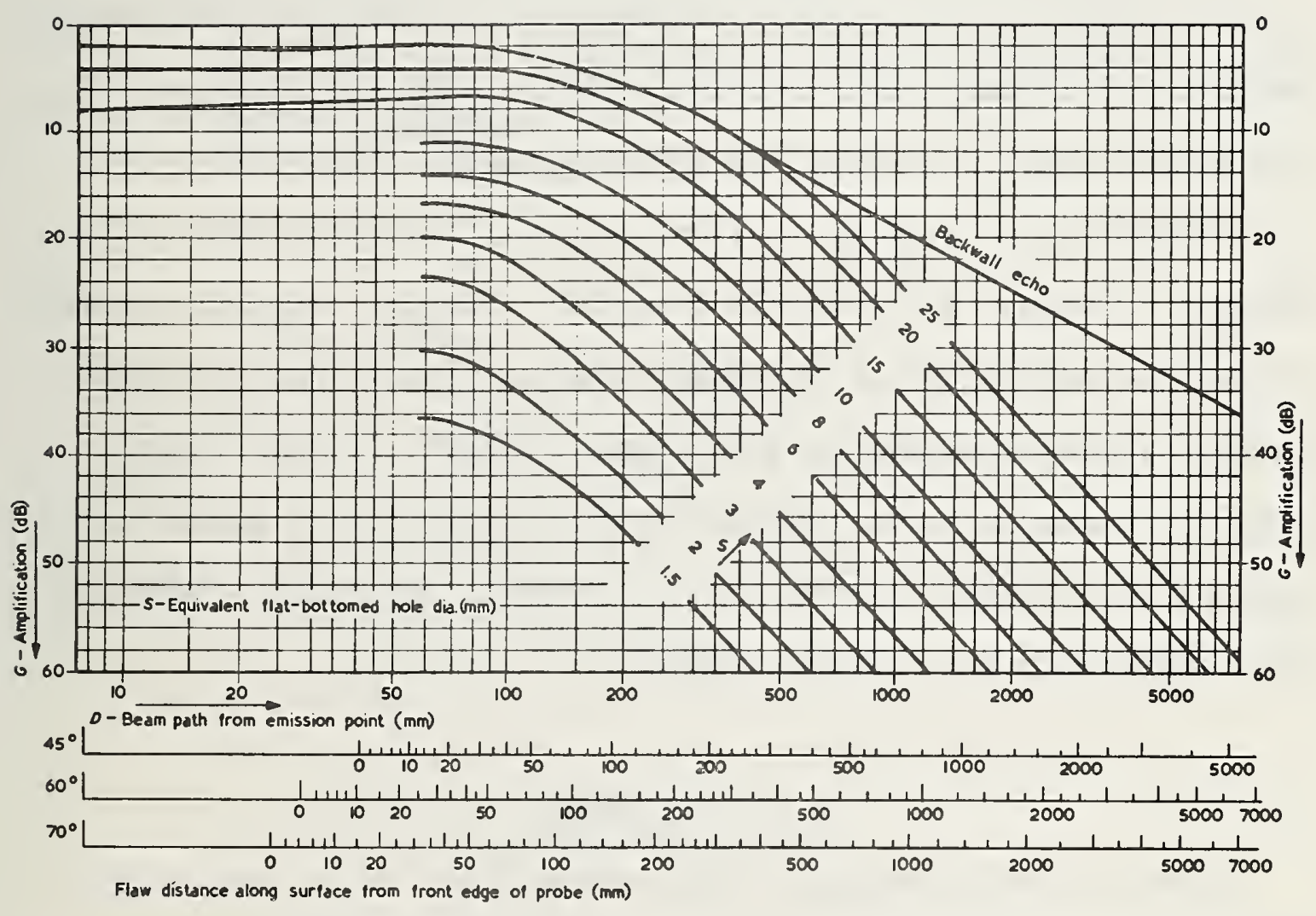

Fiqure 11. Typical D.G.S. diagram for angle probe of $4 \mathrm{MHz}$, $8 \mathrm{~mm} \times 9 \mathrm{~mm}$ crystal size. (I17ustration from BS 3923 part 2) 


\subsection{Method for U1trasonic Inpsection of Turbine and}

Compressor Discs Using the (DGS) Diagram, DD28 (1973)

\subsubsection{Synopsis}

DD28, a Draft for Development, is not yet a recognized standard. It was reviewed in this study as an example of an advanced, quantitative technique of the pulse-echo immersion method. With this technique the size of the flaw is determined by applying the DGS diagram (Figs. 10, 11). Parameters such as attenuation, beam characteristic, near field, dominant frequency, and effective transducer diameter, which can usually be neglected when applying the conventional pulse-echo flaw-detection technique, must be determined with great precision. A detailed procedure to determine these parameters and to calibrate the system is outlined. The system consists of an instrument, transducer, immersion tank, manipulator and reference blocks.

\subsubsection{Evaluation}

DD28 for testing compressor and turbine discs in the aero-engine industry is an example of how an advanced, quantitative, pulse-echo technique is used. The procedures outlined are suitable for inspection of other products as well. The use of this technique requires more elaborate testing facilities and more experienced and knowledgeable 
operators than less quantitative techniques. A preliminary knowledge of the nature and orientation of the $f l$ aws is desirable in order to reduce the amount of work and obtain reliable results.

The added complexity of this method might be justified for inspection of parts where a high degree of safety is required or a high economic leverage is apparent. 
2.8 Recommended Practice for U7trasonic Testing By The Reflection Method Using Pulsed Longitudinal Waves Induced by Direct Contact, ASTM E-114/ASME SE-114 (1975)

\subsubsection{Synopsis}

This standard consists of a general and brief explanation of the contact normal-beam, pulse-echo technique. It gives very general recommendations for surface preparation, choice of frequency and speed and method of scanning.

\subsubsection{Evaluation}

This recommended practice is a general and short description of factors that have to be considered in preparing to conduct an ultrasonic test. Usually product standards contain a more detailed description of the various parameters and do not refer to this standard. 
2.9 Recommended Practice for Immersed Testing by the Reflection Method Using Pulsed Longitudinal Waves, ASTM E-214/ASME SE-214 (1974)

\subsubsection{Synopsis}

This standard describes, in general terms, the factors that should be considered in the preparation of an ultrasonic immersion test.

Recommendations are given for frequency selection, surface preparation, scanning technique, reference blocks, sensitivity level and system linearity.

\subsubsection{Evaluation}

Although this recommended practice is more specific than ASTM E-114, it is still a very general description. The product standards contain more detailed and specific procedures and, thus, rarely refer to this recommended practice. 


\subsection{Recommended Practice for UTtrasonic Testing}

and Inspection of Heavy Forgings,

ASTM A-288/ASME SA-388 (1978)

\subsubsection{Synopsis}

This recommended practice is an inspection procedure for heavy steel forgings using normal and angle-beam contact techniques. It describes the transducer, couplant, surface preparation and scanning conditions. The linearity of the system is verified in accordance with ASTM E-317.

To establish the sensitivity level, a bottom echo is used for the normal-beam technique and an echo reflected from a notch for the anglebeam technique. Reference blocks should have acoustical properties identical with those of the tested material. Guidance for the recording of data and for reporting are given. Also, general criteria to establish quality levels are described.

\subsubsection{Evaluation}

This standard is a very practical and detailed procedure for the inspection of forged products. The guidance given in this standard can serve to establish ultrasonic inspection specifications for a very wide range of forged steel products. The standard is presented and formulated in a very clear and simple way. 
2.11 Standard Recommended Practice for Evaluating Performance Characteristics of Pulse-Echo UItrasonic Testing Systems, ASTM E-317 (1968)

\subsection{1 .1 Synopsis}

This recommended practice is a detailed description of a procedure for checking the characteristics of an ultrasonic testing system in order to evaluate its performance. The system includes the instrument, connecting cable, transducer, couplant, tank and manipulator and reference blocks.

The characteristics are established from indications obtained from ASTM aluminum reference blocks (see ASTM E-127) and some complementary blocks without holes.

The following parameters are determined:

1. Vertical limit and vertical linearity.

2. Sensitivity.

3. Signal-to-noise ratio.

4. Entry resolution (dead zone) and back surface resolution.

5. Horizontal limit and horizontal linearity.

6. Penetration. 


\subsubsection{Evaluation}

ASTM E-317 provides a simple and clearly defined method to determine some important performance characteristics by which the capability of an ultrasonic system can be evaluated.

This standard and the BS 4331, Part 1 (see page 17), are apparently the only standards that characterize ultrasonic systems independently of the in-use conditions. This is a distinct asset as independent characterization makes it possible to compare performance characteristics of different ultrasonic systems. Although for a more detailed examination of the units of an ultrasonic system, such as the transmitter, the sweep generator, the amplifier, etc., special electronic testing facilities are required, for most practical uses such a thorough testing is not necessary. Most nondestructive testing laboratories also do not have the equipment nor the knowledge to carry out electronic measurements. The simple and practical method outlined in this standard enables one to check many system characteristics which determine the quality of a test without the use of additional electronic equipment. 


\subsection{Standard Recommended Practice for Fabricating and Checking of Aluminum Reference Blocks, ASNT/ASTM E-127 (1975)}

\subsubsection{Synopsis}

This is a recommended practice for fabricating and checking aluminum flat-bottom hole reference blocks (Figure 12) which are used to establish performance characieristics of ultrasonic flaw detection systems and to standardize and control the adjustment of systems for the inspection of aluminum products. They also are used to establish accept-reject criteria for many wrought aluminum products. Procedures for inspection of the material quality, fabrication of blocks and evaluation of their physical and ultrasonic characteristics are described.

The acoustic properties of the material are checked against a steel ball reference reflector. The characteristic of the transducer for checking the blocks is derived from echoes from a steel ball reflector. The linearity of the system for checking the material and calibrating the block is determined in accordance with ASTM E-317 (see pages 39-40).

The blocks are characterized by their distance-amplitude and areaamplitude responses (Figures 13 and 14). Ultrasonic differences between the blocks and the inspected material should be considered when standardizing systems for inspection of aluminum products. There are three 
standard sets: the basic set which consists of blocks with several hole sizes and metal distances; the area-amplitude set with blocks of different hole sizes and equal metal distances; and the distance-amplitude set which contains blocks with equal hole sizes and different metal distances.

\subsubsection{Evaluation}

This standard is a very detailed description for fabricating and checking aluminum reference blocks. These blocks are mainly used in the United States as a primary reference source for evaluating the performance characteristics of Uitrasonic systems (see ASTM E-317, pages 38 and 39) and for the inspection of aluminum products.

The blocks used in Europe (i.e., IIW Blocks 1 and 2, pages 11-16) and in the welding industry in the United States (see ASTM E-164, pages 48-53) are suitable for use with normal and angle-beam techniques, while the ASTM flat bottom hole blocks are limited to the normal-beam technique only. The flat-bottom hole reflector has a linear area-amplitude response (see Figure 14). This is an advantage when checking vertical linearity of the system. An additional advantage is that the distanceamplitude set provides a direct method for determining the DGS diagram and the dead zone. 


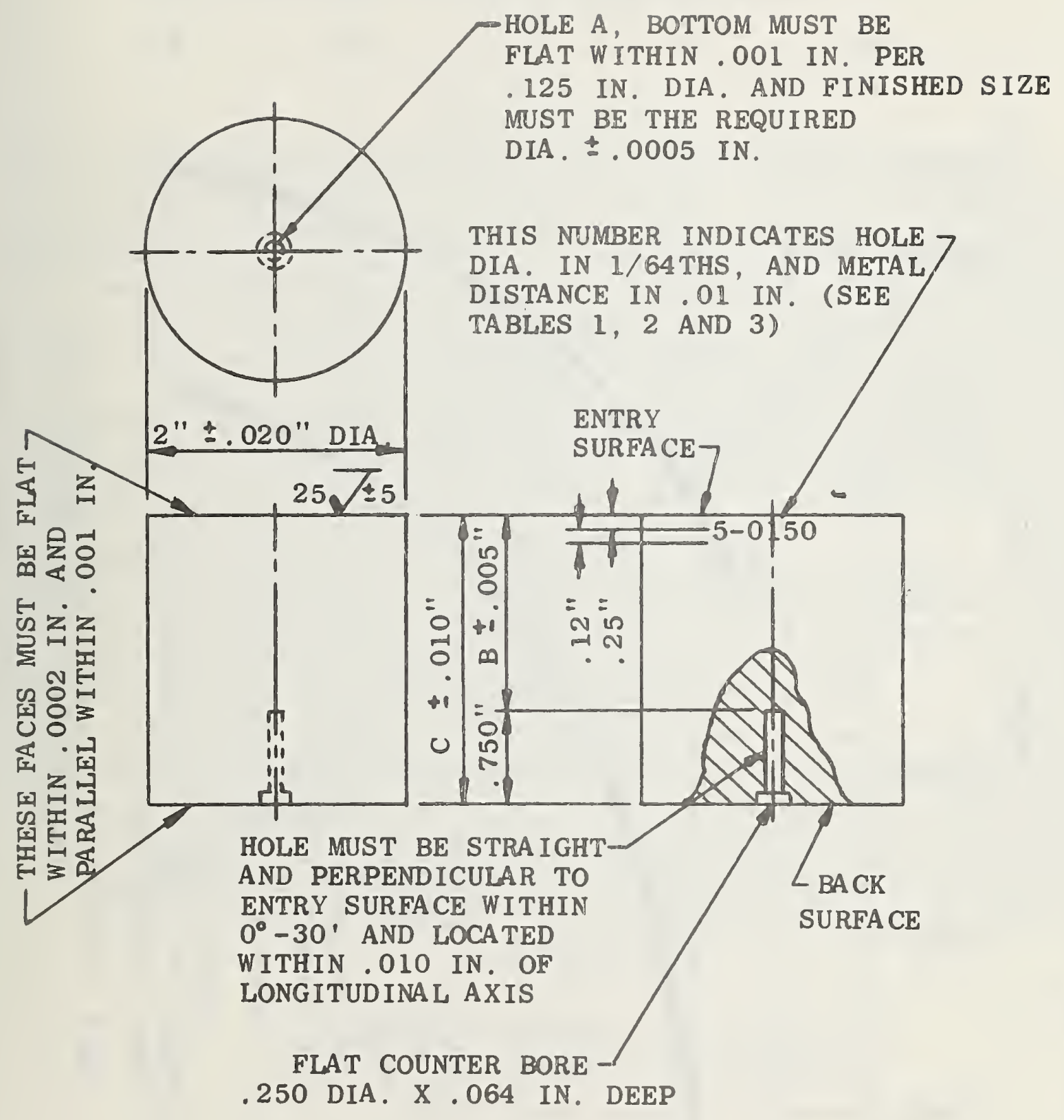

Figure 12. ASTM flat bottom hole reference block. (Illustration from ASTM E-127) 


\section{Amplitude - \% Upper Linearity Limit}

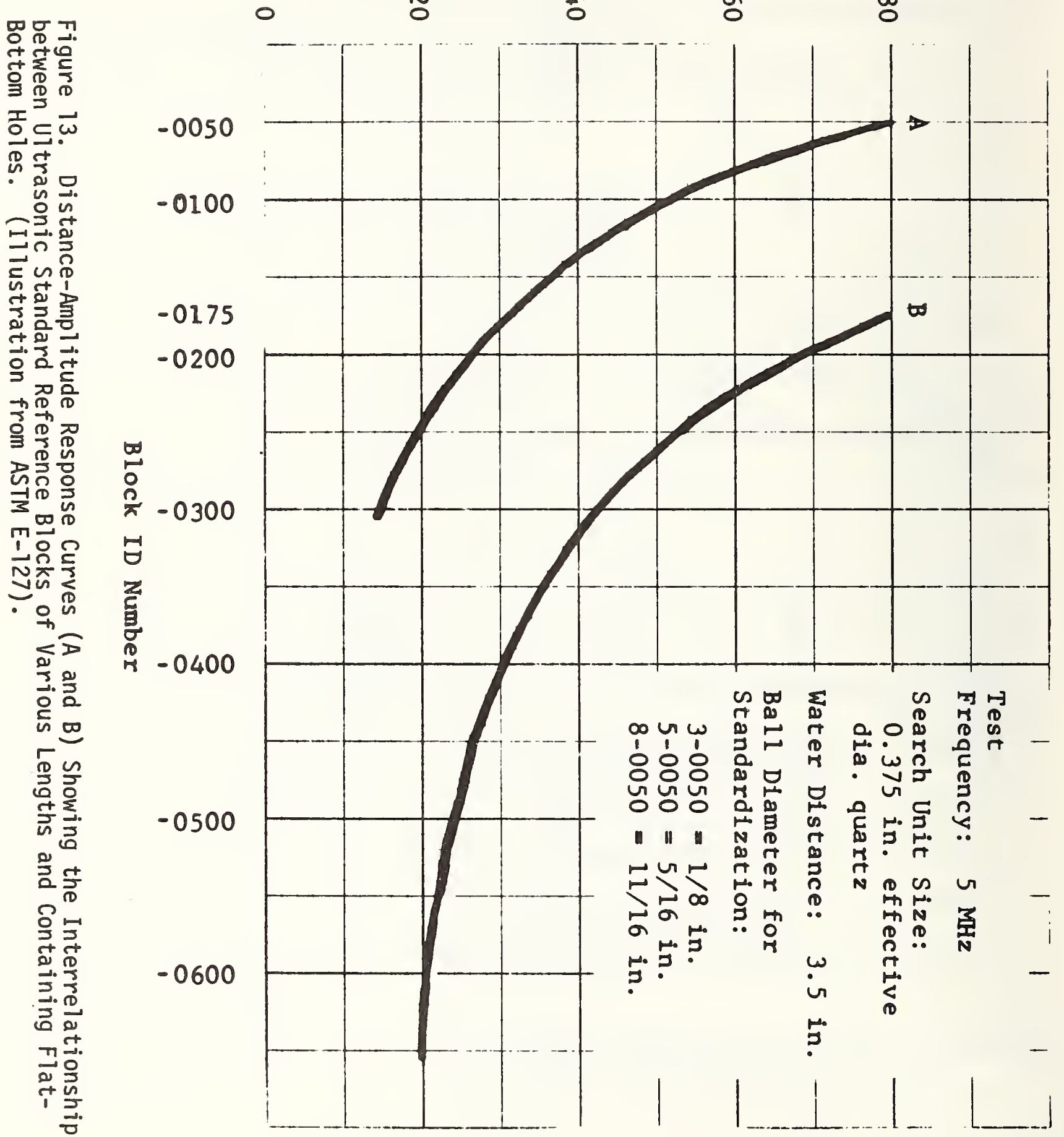




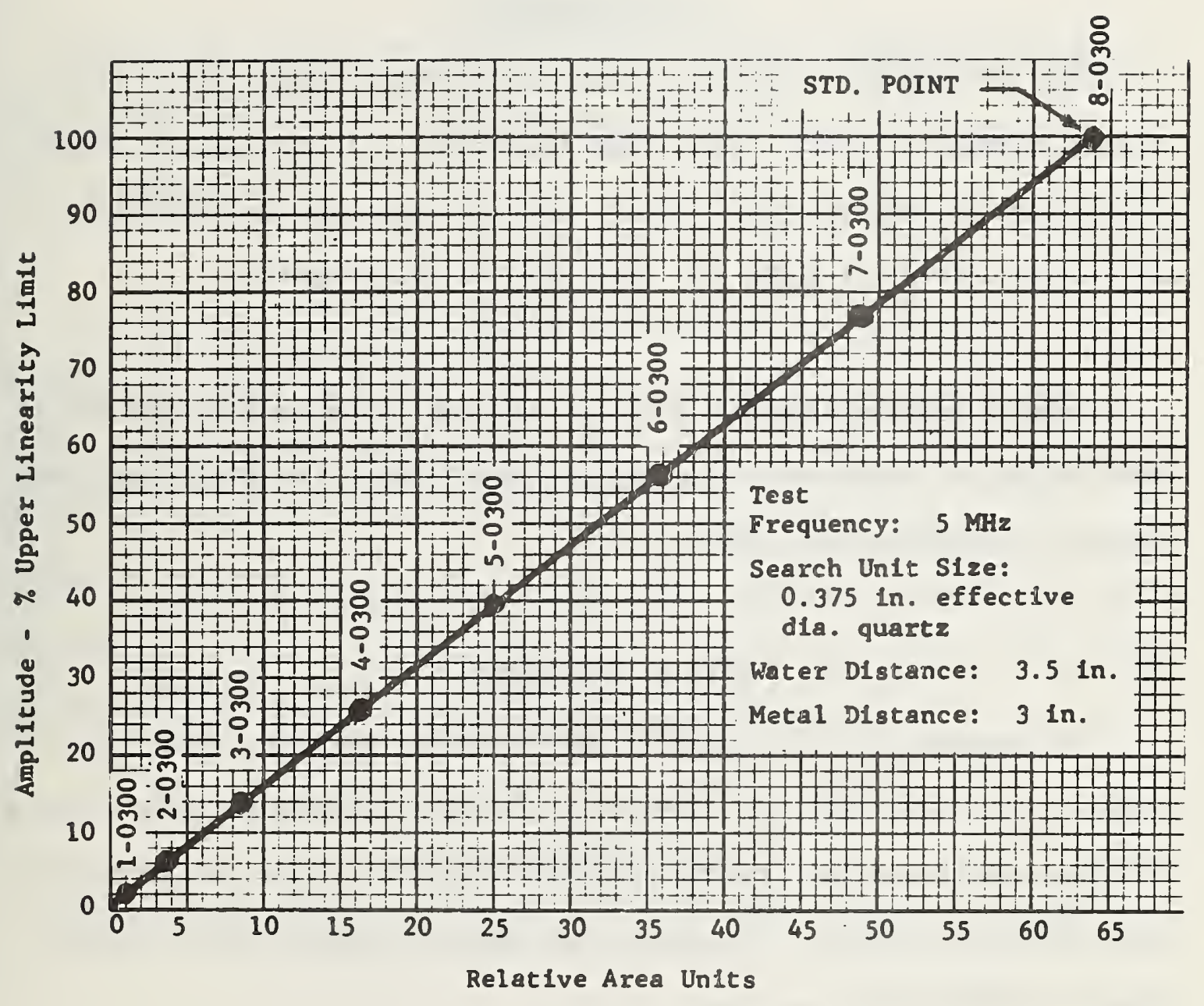

Figure 14. Area-amplitude response

curve. (I7lustration from ASTM E-127) 


\subsection{Standard Recommended Practice for U1trasonic Angle-Beam Examination by the Contact Method, ASTM E-587 (1976)}

\subsubsection{Synopsis}

This recommended practice gives a very general description of a broad spectrum of contact angle-beam techniques. It contains a brief description of compressional, shear, surface wave and lamb wave modes and how the different modes are generated in the material.

General instructions for distance and amplitude calibration and a short guide for angle-beam examination techniques using single and dual element transducers are given.

\subsubsection{Evaluation}

This standard is very general and is really more of a brief explanation and description of contact angle beam techniques rather than a procedure which can be directly applied to test or calibrate ultrasonic flaw-detection systems. The angle beam method is described in greater detail in ASTM E-164 (see pages 48-53). 


\subsection{Standard Recommended Practice of Steel Reference Blocks Used in UT trasonic Inspection, ASTM E-428 (1975)}

\subsubsection{Synopsis}

ASTM E-428 is a recommended practice for fabricating and checking flat-bottom hole blocks to be used for the testing of steel or other metal products.

The procedures for fabricating and checking the blocks are similar to those for aluminum blocks (see ASTM E-127 pages 41-45) with one principal difference. The acoustic properties of the aluminum blocks are checked against a steel ball reflector which serves as master reference, while the properties of the other blocks are checked against the properties of the inspected material. Blocks are usually fabricated from the same materials as those which are to be tested.

\subsubsection{Evaluation}

(See evaluation of flat-bottom aluminum blocks ASTM E-127 page 42). 
2.15 Standard Recommended Practice for Ultrasonic Contact Examination of Welds, ASTM E-164 (1974)

\subsubsection{Synopsis}

This standard contains a very extensive description of calibration procedures and reference blocks for testing welds using the contact, normal and angle-beam pulse-echo techniques.

The standard describes a series of reference blocks most commonly used in the United States and Europe, and it provides a variety of techniques for the most common types of system adjustment and standardization for weld inspection.

The following system parameters can be calibrated and checked with the different blocks:

1. Horizontal linearity.

2. Range and transmission point (zero point).

3. Working sensitivity.

4. Transducer central beam exit point.

5. Angle of refraction. 
6. Back-surface resolution.

7. Beam profile.

8. Distance-amplitude response.

The various blocks described in this standard are listed below:

1. IIW Block 1. A description of this block is given on p. 11 .

2. AWS Distance Calibration (DC) Block: AWS Sensitivity Calibration (SC) Block: AWS Distance-sensitivity Calibration (DSC) Block (see Figure 15).

3. Angle-beam calibration blocks (see Figure 16).

4. ASME-type basic calibration block (see Figure 17).

All tests and calibrations are performed with an ultrasonic system evaluated according to ASTM E-317.

1 Fabrication and use of ASME-type basic calibration block is described in great detail in the ASME Boiler and Pressure Vessel Code: Section V. Article 5; Section III, Appendix XVI; and Section XI, Appendix I. 

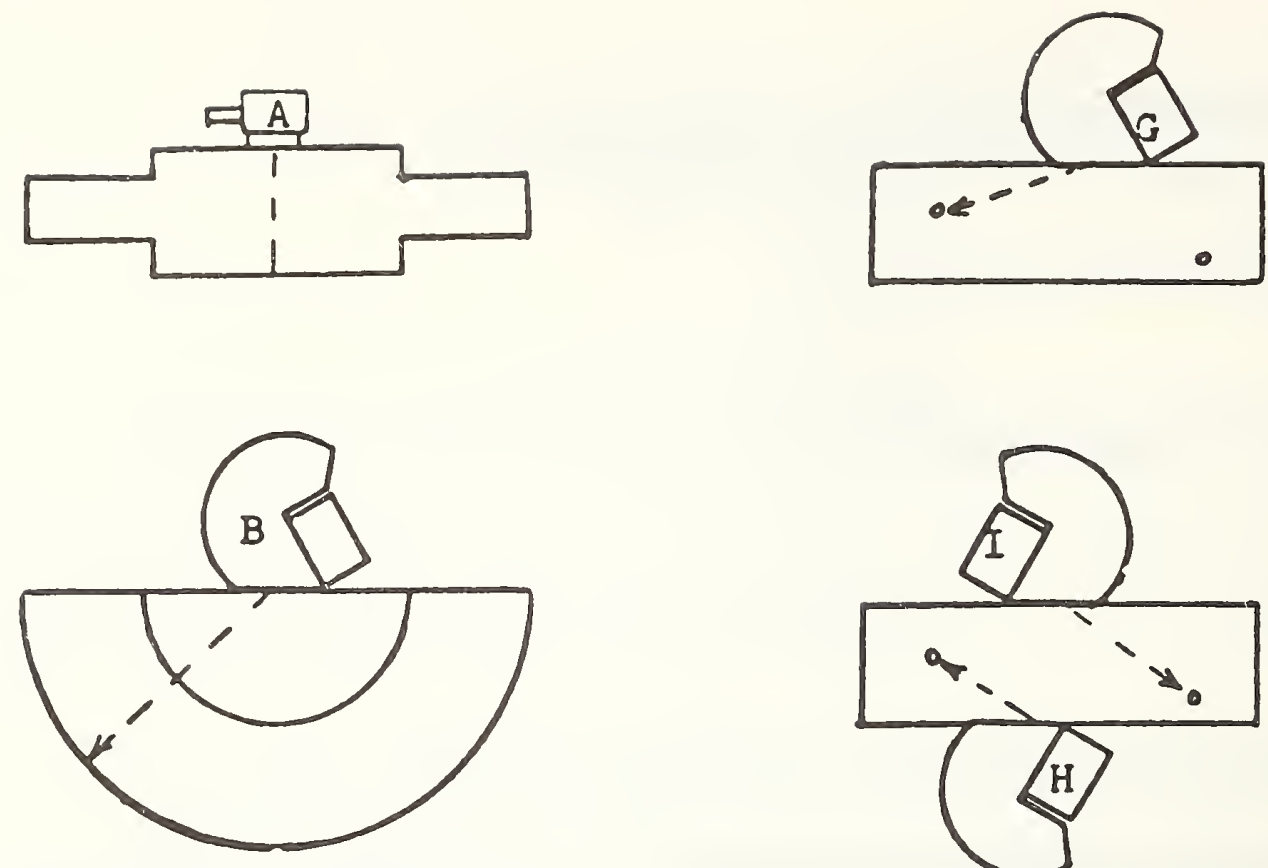

D1stance Calibration (DC Block)

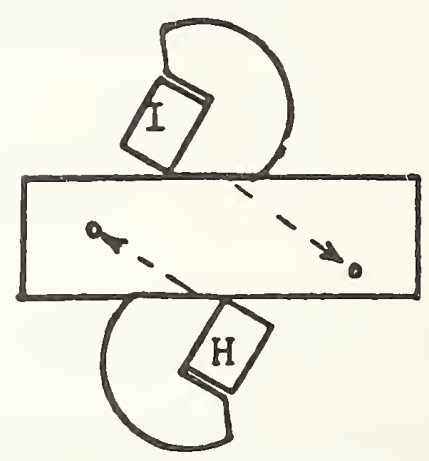

Sensitivity Calibration (SC Block)
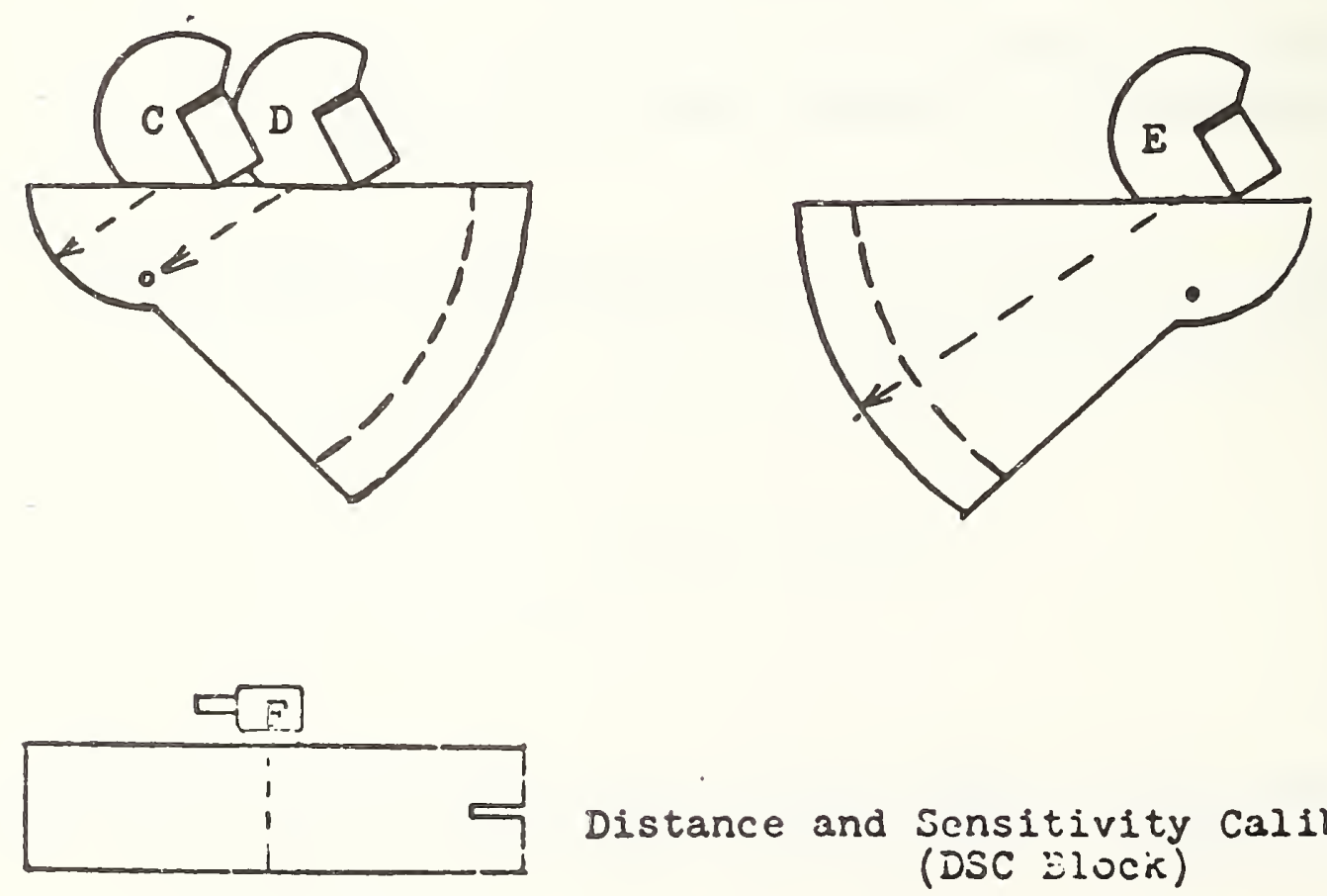

Distance and Sensitivity Calibration (DSC Elocir)

Figure 15. AlWS Calibration blocks.

(I1lustration from ASTM E-164) 


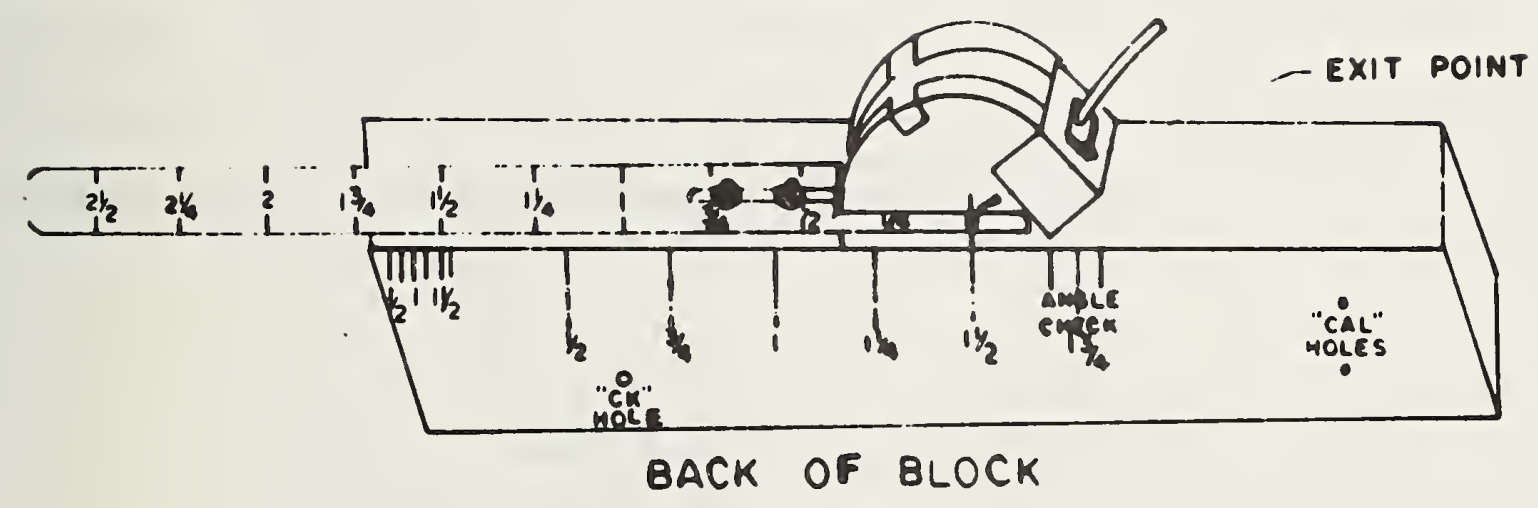

Figure 16. Angle-beam calibration block. 

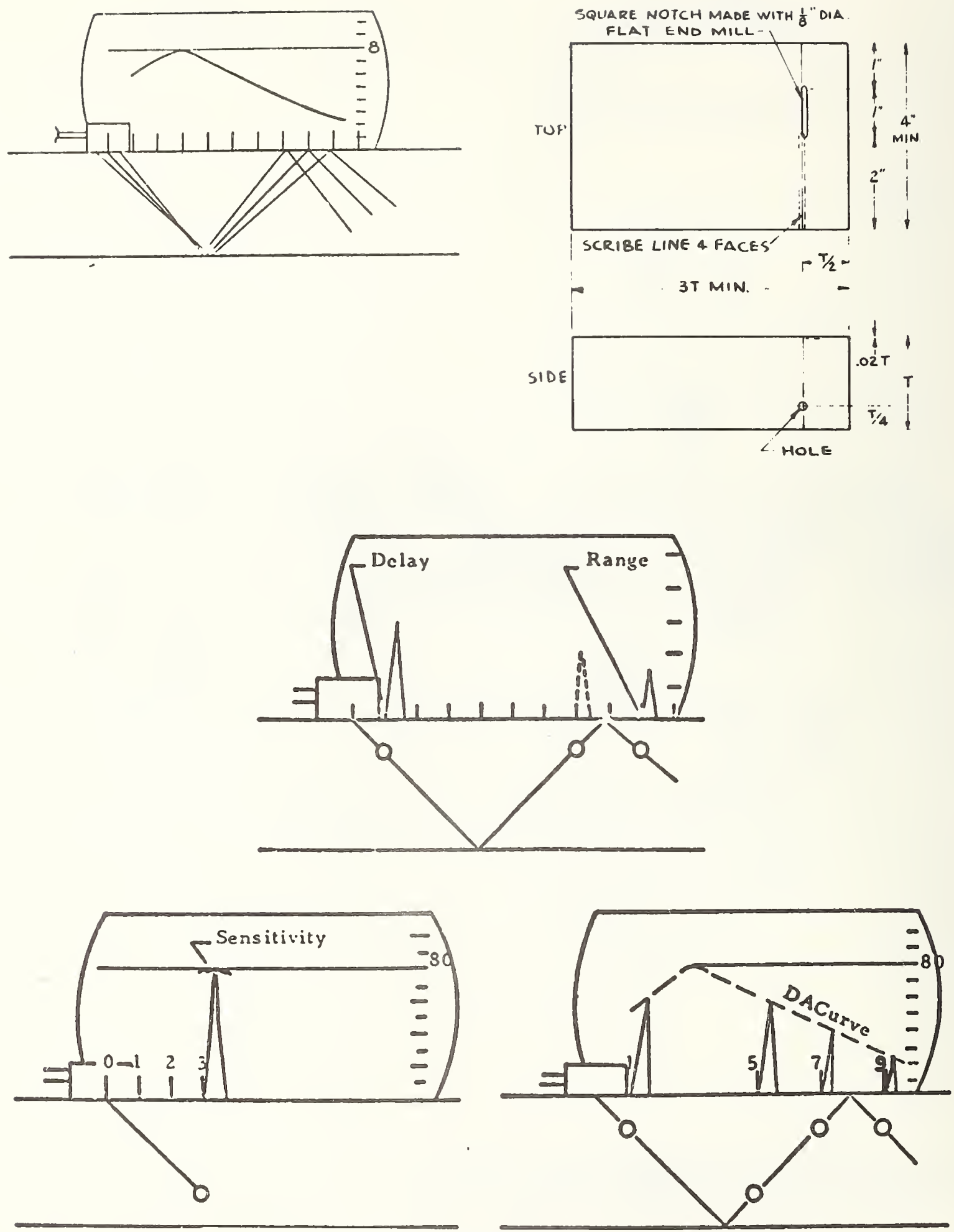

Figure 17. Basic ASME calibration block and some of its uses. (Illustration from ASTM E-169) 


\subsubsection{Evaiuation}

This standard, designed originally for the examination of welds, can actually be used for the examination of a variety of metal products. It is a very extensive and detailed description of the most common testing and calibration techniques used in the welding industry in the United States and Europe.

The standard is very product oriented. The calibrations and checks are performed with blocks made of the same material as the material to be tested. This standard provides excellent guidance for establishing specifications for weldments and other metal products. The presentation is very detailed and contains many explanatory drawings. 
2.16 Nondestructive Testing, Welded Joints Utrasonic Method, GOST 14782-76 (1976)

\subsubsection{Synopsis}

In this standard, requirements for inspection of welds with the contact, normal and angle-beam echo-amplitude techniques are given. Methods for monitoring the following parameters are described:

1. Frequency.

2. Conditional sensitivity (defined below).

3. Ultimate sensitivity (defined below).

4. Angle of refraction.

5. Depth calibration.

6. Wedge angle.

7. Dead zone.

8. Resolution (the equivalent of time base calibration).

9. Point of exit of central beam (index).

10. Effective size of transducer.

11. Pulse length.

The standard consists of six chapters. Chapter 1 deals with the evaluation of general system parameters not related to a particular test, Chapter 2 deals primarily with procedures for adjusting the sensitivity of the system for a particular test and the remaining four chapters deal with scanning methods for different configurations of welds, interpretation and documentation of results and safety requirements. 
The reference blocks are divided into two groups: "standard blocks" (Figs. 18, 19 and 20) used tc evaluate system parameters and "test blocks" (Figure 21) for adjusting and checking the sensitivity of the system for a particular test.

The system parameters evaluated in Chapter 1 are: depth (time base) calibration, frequency, wedge angle, angle of refraction, resolution, dead zone and conditional sensitivity. "Conditional sensitivity" is expressed in millimeters of depth of the farthest detectable sidedrilled hole in the standard plastic block number 1 (Figure 18). Conditional sensitivity is also expressed in decibels using the sidedrilled nole of the standard steel block number 2 (Figure 19) if the instrument is equipped with an attenuator. This parameter characterizes the threshold of detectability of the system. Other system parameters determined with block number $/$ are resclution, depth calibration and wedge angle. Block number 2 is used to monitor angle of refraction, dead zone and also to provide a depth calibration. Blocks similar to the number 2 block, but made of materials other than steel, are marked 2A. Additional standard blocks, number 3,4 and 4 a made of mild stee? (Figure 20), are used to monitor the point of exit of the central beam and the frequency.

The procedure for adjusting the sensitivity of the system for a particular test, "threshold sensitivity", is outlined in Chapter 2. "Threshold sensitivity" is defined as the area in square millimeters 
of the smallest detectable flat bottom hole located at a specified depth, for a certain adjustment of the instrument. Blocks with flat bottom and side-drilled holes and notches (Figure 21) are used to set the "threshold sensitivity". Formulas to calculate the equivalent flat bottom hole sensitivity if measurements are made with notch or sidedrilled hole reflectors are given.

\subsubsection{Evaluation}

Chapter 1 deals with rather basic parameters on which accuracy, sensitivity, reliability and comparability, namely the quality of a pulse-echo technique test depend. It may be applied to other metal products as well as to welds. In the Soviet Union this part of the standard is apparently accepted as general guidance for checking and calibrating ultrasonic test systems. Three of the ultrasonic product standards reference the procedures outlined here. (See utilization study, pages 60-61).

A failing of the standard is that it often requires determination of parameters without describing the procedures. For instance, procedures for the calibration of depth and for the monitoring of frequency and pulse length are not specified. Some of the blocks contain reflectors, the use of which is not given. Highly qualified personnel might be needed to transfer the general requirements of the standards into working procedures. 


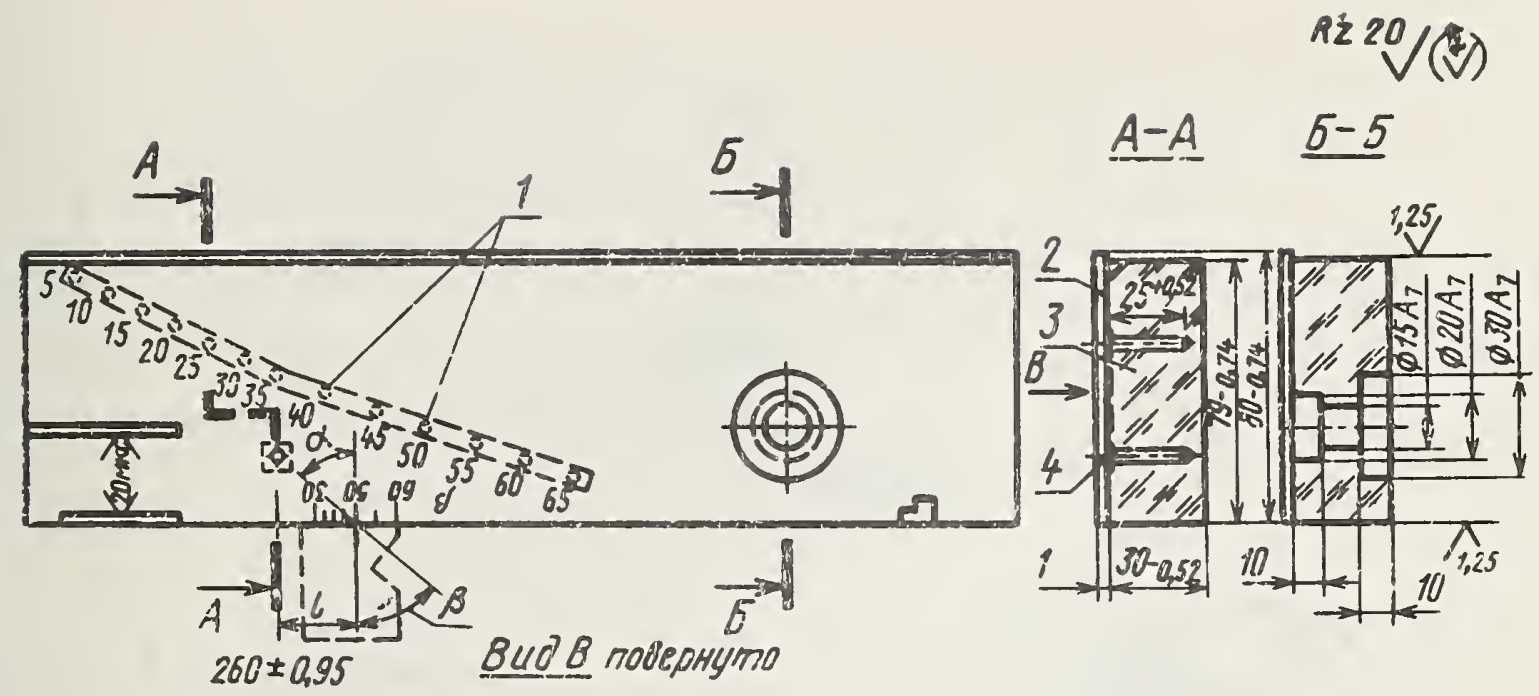

Figure 18. GOST standard block ?.

(I1lustration from GOST 14782-76)
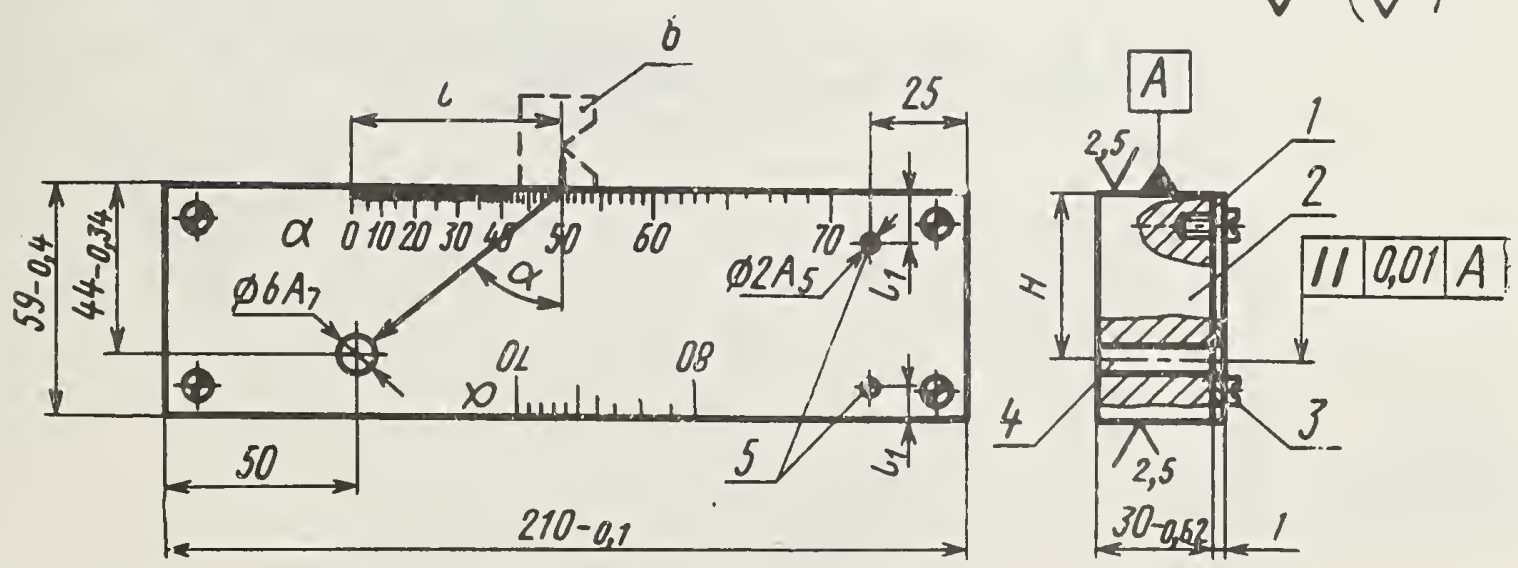

Figure 19. GOST standard block 2.

(Illustration from GOST 14782-76) 

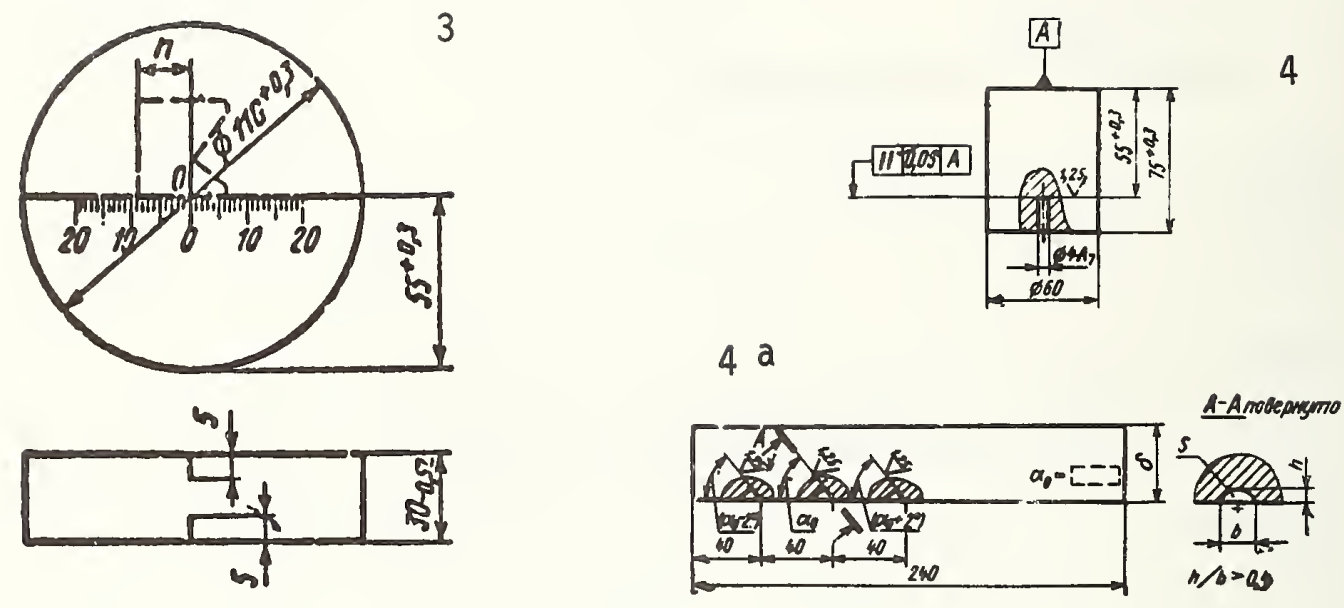

Figure 20. GOST standard blocks 3, 4 and $4 a$.

(I17ustrations from GOST 14782-76) 

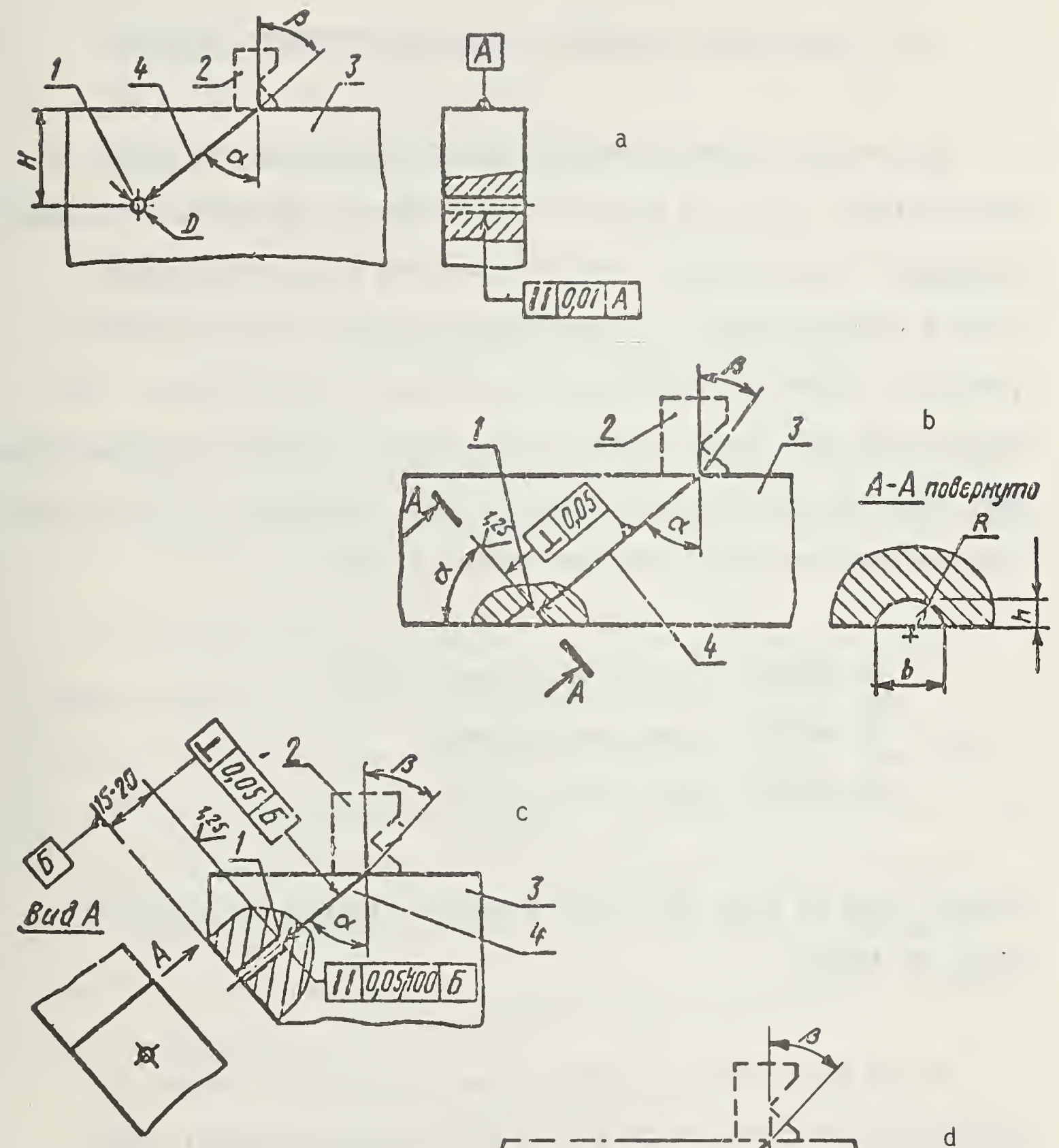

C

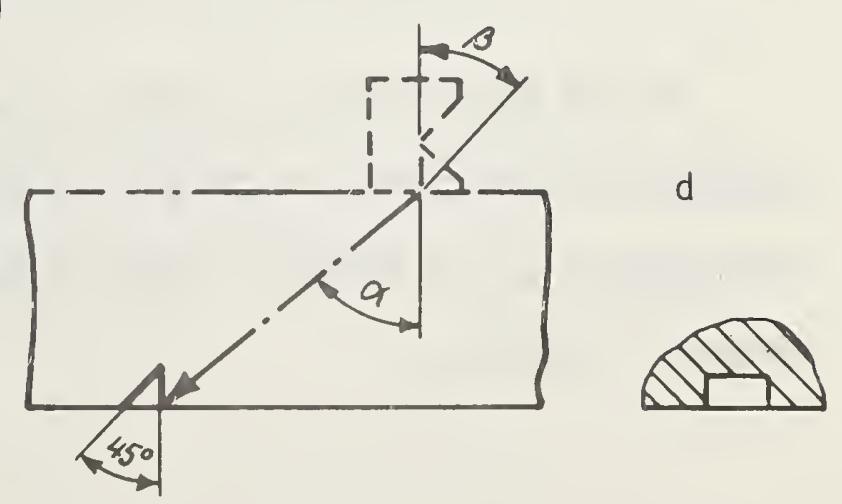

Figure 21. GOST test blocks for checking ultimate sensitivity, with (a) Side hole reflector (b) Segment reflector (c) Flat bottom hole (d) Notch reflector. 


\section{UTILIZATION OF GENERAL STANDARDS IN PRODUCT STANDARDS}

One of the criteria by which general standards may be judged is their utility, i.e., the extent to which they are referenced in product standards. It was found in this phase of the study that not many product standards exist. In most cases the ultrasonic inspection of products is based on manufacturers' and buyers' specifications. For instance the West German Standards Institution (Deutscher Normenausschuss DNA), does not promulgate ultrasonic product standards. In France, only three national ultrasonic product standards exist:

\footnotetext{
NF A04305 - inspection of steel plates;

NF A49200 - inspection of tubes;

NF A49870 - inspection of tubes.
}

However, none of these refer to the general standard for the IIW 1 Block, NF A04311.

In the Soviet Union a similar situation exists. The Soviet standards organization (USSR State Committee for Standards), which promulgates a vast number of GOST standards, has very few ultrasonic product standards. 


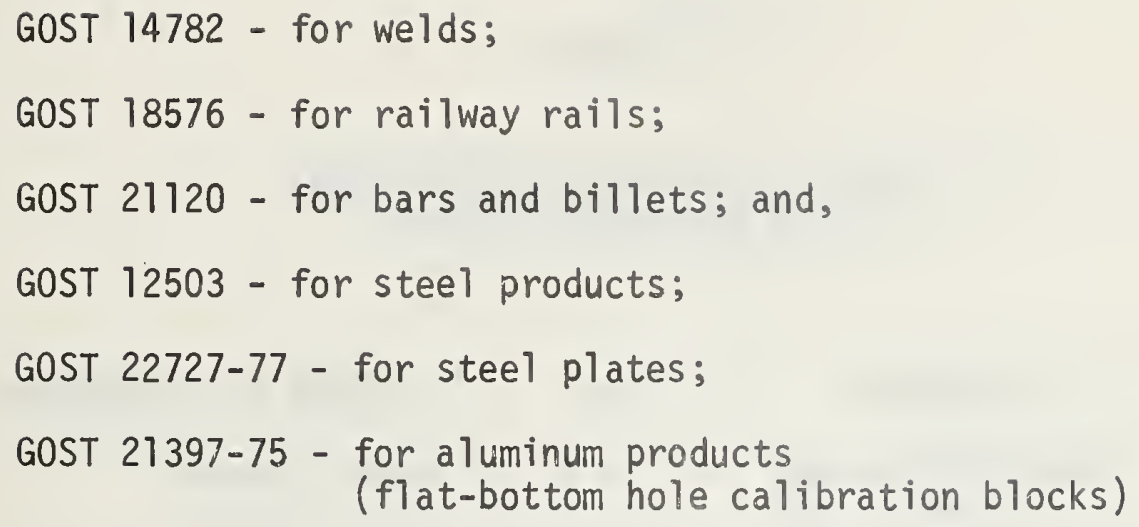

GOST 14782 is also considered to be a general standard. Three of the product standards reference procedures that are described in GOST 14782 .

The United Kingdom and the United States have more ultrasonic product standards. In this study nineteen ASTM, ASME and AWS standards as well as nine BS standards were investigated. (See Table 3.) The utility of the BS general standards is presented in Table 4. As can be seen, six of the nine British product standards refer to the two existing general standards. Table 5 shows that of the nineteen U.S. product standards, thirteen refer or base their procedures on various general standards. 
Table 3

$\frac{\text { List of Product Standards Used }}{\text { In Utilization Study }}$

\begin{tabular}{|c|c|c|c|}
\hline Country & Standard & Year & Type of Product \\
\hline U.S. & 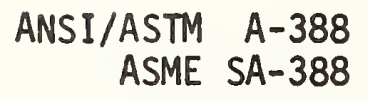 & 1978 & Steel forgings \\
\hline & $\begin{array}{r}\text { ANSI/ASTM A-435 } \\
\text { ASME SA-435 }\end{array}$ & 1975 & Steel plates \\
\hline & ANSI/ASTM A-503 & 1975 & Crankshaft \\
\hline & $\begin{array}{rr}\text { ANSI/ASTM } & A-577 \\
\text { ASME } & \text { SA-577 }\end{array}$ & 1977 & Steel plates \\
\hline & 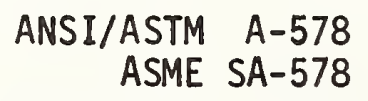 & 1977 & Steel plates \\
\hline & 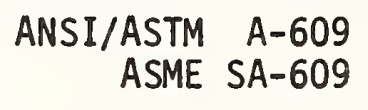 & 1978 & Steel casting \\
\hline & $\begin{array}{rr}\text { ANSI/ASTM } & B-548 \\
\text { ASME } & \text { SB-548 }\end{array}$ & 1976 & Aluminum plates \\
\hline & ANSI/ASTM B-594 & 1974 & $\begin{array}{l}\text { Aluminum wrought } \\
\text { products }\end{array}$ \\
\hline & ANSI/ASTM E-164 & 1974 & Welds \\
\hline & ANSI/ASTM E-213 & 1977 & Pipes \& tubes \\
\hline & ANSI/ASTM E-273 & 1974 & Pipes \& tubes \\
\hline & ANSI/ASTM E-588 & 1976 & Bearing quality steel \\
\hline & ANSI/ASTM A-418 & 1977 & $\begin{array}{l}\text { Turbine generator } \\
\text { steel retaining rings }\end{array}$ \\
\hline & ANSI/ASTM A745 & 1977 & $\begin{array}{l}\text { Austenitic steel } \\
\text { forgings }\end{array}$ \\
\hline
\end{tabular}


Table 3

(continued)

List of Product Standards Used

In Utilization Study

\begin{tabular}{|c|c|c|c|}
\hline Country & Standard & Year & Type of Product \\
\hline \multirow[t]{5}{*}{ U.S. } & $\begin{array}{ll}\text { ASME Sec. } & \text { V } \\
\text { Article } 5 & \text { T525 }\end{array}$ & 1977 & Bolts \& studs \\
\hline & $\begin{array}{ll}\text { ASME Sec. } & \text { A } \\
\text { Article } 5 & \text { T530 }\end{array}$ & 1977 & Welds \\
\hline & $\begin{array}{l}\text { ASME Sec. XI } \\
\text { Appendix I }\end{array}$ & 1977 & Welds \\
\hline & $\begin{array}{l}\text { ASME Sec. III } \\
\text { Appendix XVI }\end{array}$ & 1977 & Welds \\
\hline & $\begin{array}{l}\text { AWS Structural } \\
\text { welding code }\end{array}$ & 1974 & Welds \\
\hline \multirow[t]{9}{*}{ U.K. } & BS 3059 & 1968 & Pipes \& tubes \\
\hline & BS 3602 & 1962 & Pipes \& tubes \\
\hline & BS 3889 & 1965 & Pipes \& tubes \\
\hline & BS 3915 & 1965 & Nuclear reactor steel \\
\hline & $\begin{array}{l}\text { BS } 3923 \\
\text { (parts } 1,2,3 \text { ) }\end{array}$ & $1968,72,72$ & Welds \\
\hline & BS 4080 & 1966 & Steel castings \\
\hline & BS 4124 & 1967 & Steel forgings \\
\hline & BS DD28 & 1973 & Turbine discs \\
\hline & BS 4336 & 1968 & Plates \\
\hline
\end{tabular}


Table 3

(continued)

List of Product Standards Used

In Utilization Study

\begin{tabular}{llll} 
Country & Standard & Year & Type of Product \\
France & NF A04305 & 1975 & Steel plates \\
\hline NF A49200 & 1972 & Tubes \\
\hline NF A49870 & 1972 & Tubes \\
\hline U.S.S.R. & GOST 14782 & 1976 & Weids \\
\hline GOST 18576 & 1973 & Railway rails \\
\hline GOST 21120 & 1975 & Bars \& billets \\
\hline GOST 12503 & 1967 & Steel products \\
\hline GOST 22727 & 1977 & Steel plates \\
\hline GOST 21397 & 1975 & Aluminum products \\
\hline
\end{tabular}


Table 4

Utilization of Procedures Outlined In BS General Standards

\begin{tabular}{lllr}
\hline $\begin{array}{l}\text { Product } \\
\text { Standard }\end{array}$ & \multicolumn{1}{c}{ Product } & $\begin{array}{c}\text { General } \\
\text { BS 2704 }\end{array}$ & $\begin{array}{r}\text { Standards } \\
\text { BS } 4331\end{array}$ \\
\hline BS 3054 & Pipes \& tubes & & \\
BS 3602 & Pipes \& tubes & & \\
BS 3889 & Pipes \& tubes & & + \\
BS 3915 & $\begin{array}{l}\text { Nuclear reactor } \\
\text { steel }\end{array}$ & + & + \\
BS 3923 & We1ds & + & + \\
BS 4080 & Steel castings & + & + \\
BS 4124 & Steel forgings & + & + \\
BS D028 & Turbine discs & + & + \\
BS 4336 & Plates & + & + \\
\hline
\end{tabular}

+ Procedure outlined in the general ultrasonic standard is applied in the product standard. 
Table 5

Utilization of Procedures Outlined In ASTM General Standards

\begin{tabular}{|c|c|c|c|c|c|c|c|}
\hline \multirow{2}{*}{$\begin{array}{l}\text { Product } \\
\text { Standard }\end{array}$} & \multirow[t]{2}{*}{ Product } & \multicolumn{3}{|r|}{ General } & \multicolumn{2}{|l|}{ Standard } & \multirow[b]{2}{*}{$\begin{array}{r}\text { ASTM/ } \\
\text { ANSI } \\
\text { E-587 }\end{array}$} \\
\hline & & $\begin{array}{l}\text { ASNT/ } \\
\text { ANSI } \\
E-127\end{array}$ & $\begin{array}{r}\text { ASTM } \\
E-428\end{array}$ & $\begin{array}{c}\text { ASTM } \\
\text { E-114 } \\
\text { ASME } \\
\text { SE-114 }\end{array}$ & $\begin{array}{c}\text { ASTM } \\
E-214 \\
\text { ASME } \\
\text { SE-214 }\end{array}$ & $\begin{array}{l}\text { ASTM } \\
E-317\end{array}$ & \\
\hline 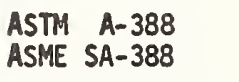 & $\begin{array}{l}\text { Steel } \\
\text { forging }\end{array}$ & + & & & & + & \\
\hline 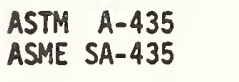 & $\begin{array}{l}\text { Steel } \\
\text { plates }\end{array}$ & & & & & & \\
\hline ASTM A-503 & Crankshaft & & + & & & + & \\
\hline 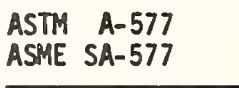 & $\begin{array}{l}\text { Steel } \\
\text { plates }\end{array}$ & + & & & & & \\
\hline $\begin{array}{l}\text { ASTM } \begin{array}{r}A-578 \\
\text { ASME }\end{array} \text { SA-578 }\end{array}$ & $\begin{array}{l}\text { Steel } \\
\text { plates }\end{array}$ & + & & & & & \\
\hline 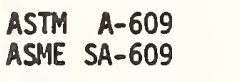 & $\begin{array}{l}\text { Steel } \\
\text { casting }\end{array}$ & & & & & & \\
\hline $\begin{array}{l}\text { ASTM } B-548 \\
\text { ASME SB-548 }\end{array}$ & $\begin{array}{l}\text { Aluminum } \\
\text { plates }\end{array}$ & + & & + & + & + & \\
\hline ASTM. B-594 & $\begin{array}{l}\text { Al uminum } \\
\text { wrought } \\
\text { products }\end{array}$ & + & & + & + & + & · \\
\hline ASTM E-164 & Helds & + & & & & + & + \\
\hline $\begin{array}{l}\text { ANSI/ASTM } \\
\text { E-213 }\end{array}$ & $\begin{array}{l}\text { Pipes } \\
\text { tubes }\end{array}$ & & & & & & \\
\hline ASTM E-273 & $\begin{array}{l}\text { Pipes \& } \\
\text { tubes }\end{array}$ & & & & & & \\
\hline $\begin{array}{l}\text { ANSI/ASTM } \\
\text { E-588 }\end{array}$ & $\begin{array}{l}\text { Bearing } \\
\text { quality } \\
\text { steel }\end{array}$ & & + & & + & & \\
\hline ASTM A-745 & $\begin{array}{l}\text { Austenitic } \\
\text { steel } \\
\text { forging }\end{array}$ & & & & & & \\
\hline ASTM A-418 & $\begin{array}{l}\text { Turbine } \\
\text { generator } \\
\text { retaining }\end{array}$ & $\begin{array}{l}\text { steel } \\
\text { rings }\end{array}$ & + & & & + & \\
\hline $\begin{array}{ll}\text { ASME Sec. } & V \\
\text { Article } 5 & \text { T525 }\end{array}$ & $\begin{array}{l}\text { Bolts \& } \\
\text { studs }\end{array}$ & & & & & & \\
\hline $\begin{array}{l}\text { ASME Sec. } V \\
\text { Article } 5 \text { T530 }\end{array}$ & Helds & & & & & & + \\
\hline $\begin{array}{l}\text { ASME Sec. XI } \\
\text { Appendix I }\end{array}$ & Welds & & & & & & + \\
\hline $\begin{array}{l}\text { ASME Sec. III } \\
\text { Appendix XVI }\end{array}$ & Welds & & & & & & + \\
\hline $\begin{array}{l}\text { AHS Structural } \\
\text { Welding Code }\end{array}$ & Welds & & & & & & + \\
\hline
\end{tabular}

+ Procedure outlined in the general ultrasonic standard is applied in the product standard. 


\section{DISCUSSION}

There are two different approaches which can be taken in the philosophy of formulating general ultrasonic testing standards. One is to establish "universal" measurement standards, against which all calibrations will be based. The other is to establish special reference standards for each specific case. The formulation of most general ultrasonic testing standards is usually a compromise between these approaches. In the United States the tendency is more toward the "universal" approach, while the European general standards are usually more "specific" and product oriented.* For instance, European standards usually do not require a general evaluation of the ultrasonic system as outlined in ASTM E-317. Usually, only a calibration and adjustment for the particular work in hand, as outlined in DIN 54120 and similiar standards, are required.

* In Europe an attempt also has been made by IIW and by ISO to prepare standards of a "universal" nature for the evaluation of systems and components. Some of the working documents include IIW VC-236-72/DE, IS0 135/2/WG 1 on Characterization of Equipment - West Germany; IS0-1973 Proposal on Characterization of Systems and ISO TC-310-75 on Search-unit Characterization - The Netherlands. 
The potential advantage of general procedures and the characterization of ultrasonic systems is that it leads to universal comparability standards for systems and products. By determining an absolute system response characteristic, the only remaining unknown variable will be the actual ultrasonic response of the tested product. On the other hand, the "specific" general standards are limited to specific conditions. Unfortunately, most of the parameters are influenced by the properties of the tested material, the system component characteristics (apparatus and transducer) and the working conditions. These influences usually cannot be analyzed independently. Therefore, when testing hardware items, special and detailed specifications have to be used.

Since an absolute response characteristic is not yet attainable, European standards usually depend on the characteristics of systems which were established under conditions simulating the conditions of the work at hand (the "specific" approach). The following citations from European standards will illustrate the philosophy of the European standards community as it applies to ultrasonic testing:

(1) BS 4331 Pt. 3 1974. - "Where probes or instruction on procedures are issued from a central source, it should be remembered that characteristics of equipment on site may sometimes differ significantly from those of the master test... 
"Since the properties here referred to as probe characteristics are in fact influenced by the acoustical and electronic characteristics of the system as a whole (and including certain characteristics of the work piece), it is essential that all checks are carried out with the testers own flaw detector and under conditions as nearly as possible identical with those involved in the particular work in hand..."

DIN 54120 - 1973 - "Since it is essential to take account of the specific properties of the equipment and the test conditions, it is not possible, without further information, to state an absolute index of indication sensitivity which is universally true."

It seems that differences in the definitions of some terms and the use of different reference reflectors stem from this difference between the American and the European philosophies of standardization.

The different concepts can be illustrated by comparing the definitions of the term sensitivity in the U.S. standard ASTM E-317 ("universal" concept) and in the West German standard DIN 51220 and the British standard BS 2704 ("specific" concept). Although the meaning of sensitivity is the same in all three standards and it is always related to the smallest detectible reflector, its definition and formulation is 
different. In ASTM E-317, ultrasonic sensitivity is a parameter of the system itself, independent of the specific work to be performed. It is calculated from the ratio of the maximum height of the echo-amplitude obtained from ASTM block 1-0300 and the upper linearity limit. In the European standards independent system sensitivity is not determined. Only equipment sensitivity and sensitivity of indication related to specific work are determined. The sensitivity of indication is explored on the test piece itself and then standardized against a standard reflector in order to check and readjust the system. This same concept is used in American product standards (e.g. , ASTM E-273 for spiral welded pipes, A-388 for steel forgings, etc.). When comparing standards from different sources, differences in definition, formulation and terminology should be considered.

Apparently, the use of different reference reflectors in the general standards in the United States and in Europe is also connected with the different concepts of standardization. In the United States, primarily flat-bottom holes are used as reference reflectors (see ASTM E-127, E-317 and E-428). These have a linear area-amplitude relationship which makes the general evaluation of systems simpler and permits direct determination of DGS diagrams. In Europe, however, where the system is usually calibrated in conjunction with specific work, the most commonly used reference reflectors are side-drilled 
holes. These are simpler to fabricate and in some cases, especially in welds and castings, they more frequently resemble real flaws of spherical and cylindrical shapes. When testing hardware items, especially welds, the side-drilled hole is the commoniy used reference reflector in the United States (ASME basic calibration blocks) as well as in Europe.

\subsection{Summary of Discussion}

In the U.S. the "general" approach and the flat-bottom hole standard reflector is used more often, while in Europe the "specific" approach and the side-drilled hole reflector is preferred. This division, however, is not very distinct. Many European standards such as GOST 14782-76, 12503-67 and 21397-75, BS 2704 and D.D28 have used flat-bottom hole reflectors. In the U.S. the side-drilled hole has been utilized in ASTM E-164 and E-587, in ASME specifications for the examination of welds and plates, and in the AWS welding code. The "general" approach utilized in the evaluation of ultrasonic testing systems in the U.S. (see ASTM E-317) can also be found in BS 4331 part 1. Other standards for the general evaluation of systems are in preparation by ISO and IIW (see footnote p. 66). It seems that due to the flow of information, and the international standardization activities of ISO and IIW, the differences are tending to become less distinct. 


\section{$\underline{\text { References }}$}

1. R. S. Sharpe, M. A. Cole and W. C. Heselwood, Qual ity Technology Handbook. Pp. 306-334 (JPC Science and Technology Press Ltd. 1975).

2. J. Krautkramer and H. Krautkrämer, Ultrasonic Testing of Materials, 2nd Edition pp. 600-604 (Springer-Verlag, Berlin, Heidelberg, New York, 1977).

3. Commonly Used Specifications and Standards for Nondestructive Testing, Materiais Evaluation, Vol. 29, No. 5, p. 17A (May 1971). 
NBS-114A (REV. 9-76)

\begin{tabular}{|c|c|c|}
\hline $\begin{array}{l}\text { U.S. DEPT. OF COMM. } \\
\text { BIBLIOGRAPHIC DATA } \\
\text { SHEET }\end{array}$ & $\begin{array}{l}\text { 1. PUBLICATION OR REPORT NO. } \\
\text { NBSIR 79-1790 }\end{array}$ & 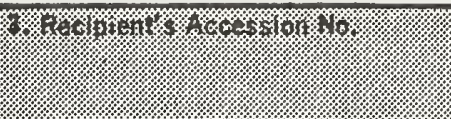 \\
\hline \multirow{2}{*}{\multicolumn{2}{|c|}{$\begin{array}{l}\text { 4. TITLE AND SUBTITLE } \\
\text { A Comparison of American and European UTtrasonic } \\
\text { Testing Standards }\end{array}$}} & 5. Publication Date \\
\hline & & 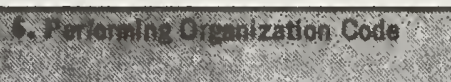 \\
\hline \multicolumn{2}{|l|}{$\begin{array}{l}\text { 7. AUTHOR(S) } \\
\text { Sam Golan }\end{array}$} & 8. Performing Organ. Report No. \\
\hline \multirow{2}{*}{\multicolumn{2}{|c|}{$\begin{array}{l}\text { NATIONAL BUREAU OF STANDARDS } \\
\text { DEPARTMENT OF COMMERCE } \\
\text { WASHINGTON, DC } 20234\end{array}$}} & 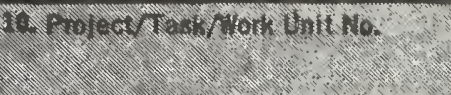 \\
\hline & & 11. Contract/Grant No. \\
\hline \multirow{2}{*}{\multicolumn{2}{|c|}{ 12. SPONSORING ORGANIZATION NAME AND COMPLETE ADDRESS (Streot, City, state, ZIP) }} & 13. Type of Report \& Period Covered \\
\hline & & 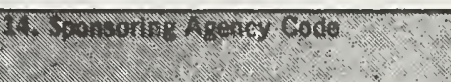 \\
\hline
\end{tabular}

15. SUPPLEMENTARY NOTES

Document describes a computer program; SF-185, FIPS Software Summary, is attached.

16. ABSTRACT (A 200-word or loss factual summary of most sigrificant information. If documerit includes a significant bibliography or literature survey, mention it here.)

In this work twenty-seven general ultrasonic standards from eleven countries and international organizations were reviewed. Thirty-seven ultrasonic product standards from five countries were studied to evaluate the utilization of the general ultrasonic standards, i.e., to what extent the procedures outlined in the general standards are applied by the product standards.

17. KEY WORDS (six to twelve entries; alphabetical order; capitalize only the first letter of the firat key word unlese a proper name; soparated by somicolons)

Evaluation; international; standard recommended practice; standardization; synopsis; ultrasonic standards; ultrasonic testing.

\begin{tabular}{|c|c|c|}
\hline $\begin{array}{l}\text { 18. AVAILABILITY } \\
\square \text { For Official Distribution. Do Not Release to NTIS }\end{array}$ & $\begin{array}{l}\text { 19. SECURITY CLASS } \\
\text { (THIS REPORT) } \\
\text { UNCLASSIFIED }\end{array}$ & $\begin{array}{l}\text { 21. NO. OF } \\
\text { PRINTED PAGES } \\
\quad 74\end{array}$ \\
\hline $\begin{array}{l}\square \text { Order From Sup. of Doc., U.S. Government Printing Office, Washington, DC } \\
\text { 20402, SD Stock No. SNO03-003- }\end{array}$ & $\begin{array}{l}\text { 20. SECURITY CLASS } \\
\text { (THIS PAGE) }\end{array}$ & 22. Price \\
\hline $\begin{array}{l}\square \text { Order From National Technical Information Service (NTIS), Springfield, } \\
\text { VA. } 22161\end{array}$ & UNCLASSIFIED & $\$ 5.25$ \\
\hline
\end{tabular}


